(1) norden

\title{
Undeclared allergens in food
}

Food control, analyses and risk assessment

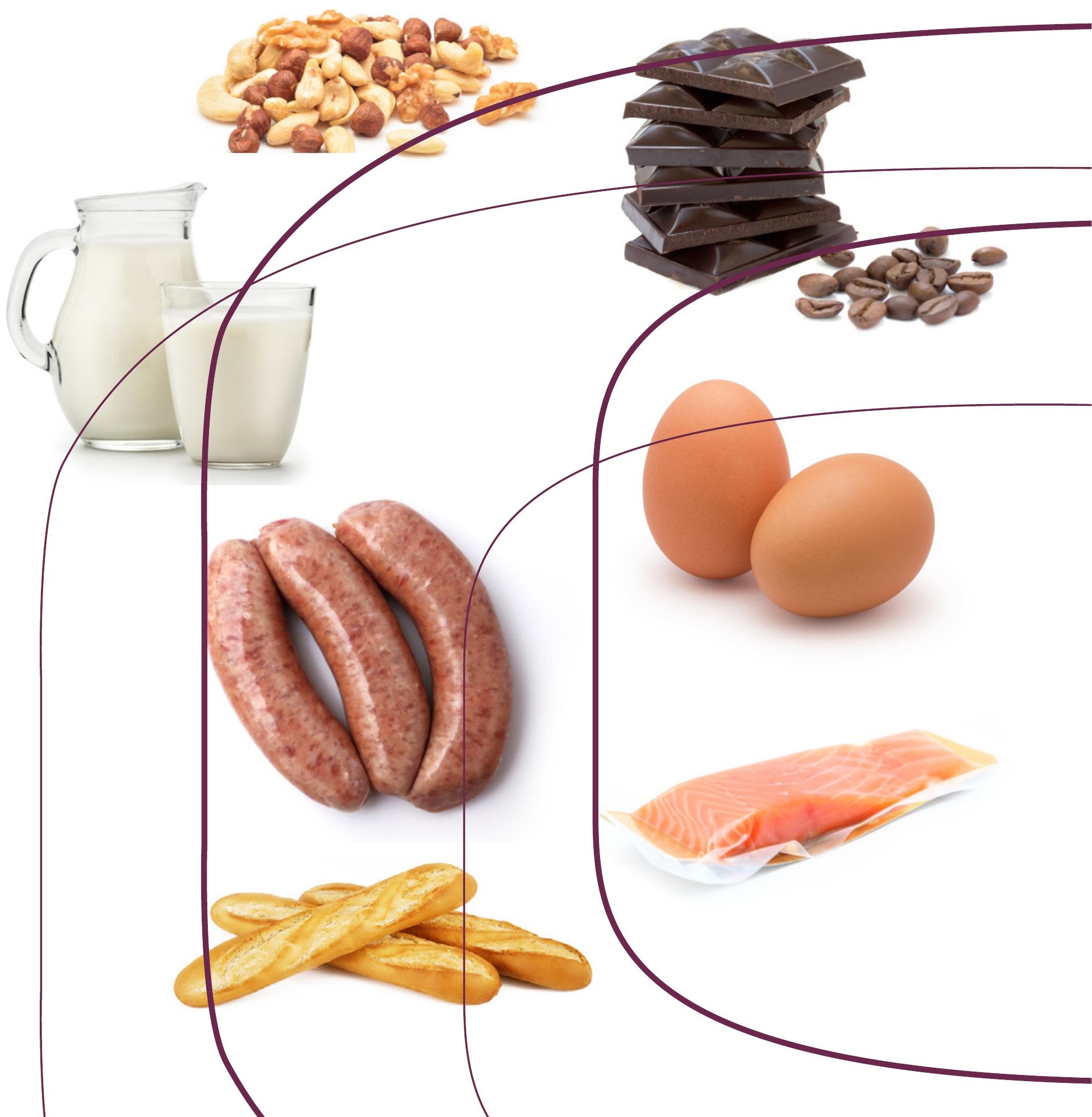





\section{Undeclared allergens in food}

Food control, analyses and risk assessment

Ylva Sjögren Bolin and Ingrid Lindeberg

TemaNord 2016:528 
Undeclared allergens in food

Food control, analyses and risk assessment

Ylva Sjögren Bolin and Ingrid Lindeberg

ISBN 978-92-893-4606-1 (PRINT)

ISBN 978-92-893-4607-8 (PDF)

ISBN 978-92-893-4608-5 (EPUB)

http://dx.doi.org/10.6027/TN2016-528

TemaNord 2016:528

ISSN 0908-6692

(C) Nordic Council of Ministers 2016

Layout: Hanne Lebech

Cover photo: ImageSelect

Print: Rosendahls-Schultz Grafisk

Printed in Denmark

This publication has been published with financial support by the Nordic Council of Ministers. However, the contents of this publication do not necessarily reflect the views, policies or recommendations of the Nordic Council of Ministers.

www.norden.org/nordpub

\section{Nordic co-operation}

Nordic co-operation is one of the world's most extensive forms of regional collaboration, involving Denmark, Finland, Iceland, Norway, Sweden, and the Faroe Islands, Greenland, and Åland.

Nordic co-operation has firm traditions in politics, the economy, and culture. It plays an important role in European and international collaboration, and aims at creating a strong Nordic community in a strong Europe.

Nordic co-operation seeks to safeguard Nordic and regional interests and principles in the global community. Common Nordic values help the region solidify its position as one of the world's most innovative and competitive.

\section{Nordic Council of Ministers}

Ved Stranden 18

DK-1061 Copenhagen K

Phone (+45) 33960200

www.norden.org 



\section{Contents}

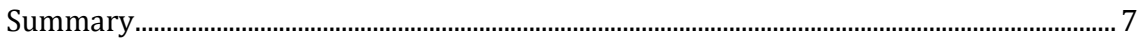

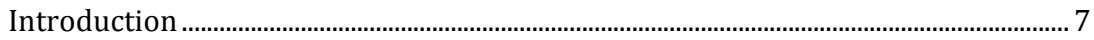

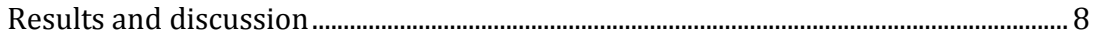

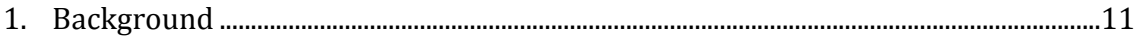

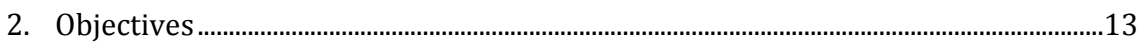

3. Organisation.......................................................................................................................15

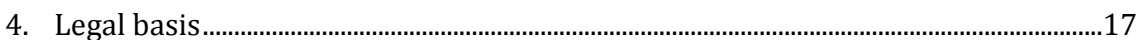

4.1 Labelling of ingredients....................................................................................18

4.2 Precautionary Allergen Labelling, hygiene, and the responsibility of the food business operator .............................................................................................20

5. Food control, sampling, and analysis of food allergens ..............................................23

5.1 Food control.............................................................................................................23

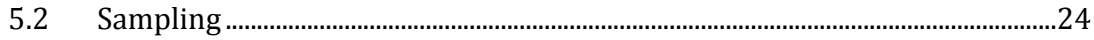

5.3 Analysis of food allergens....................................................................................2

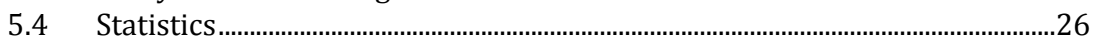

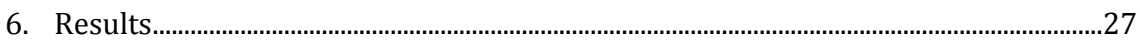

6.1 Results regarding controlled companies ..........................................................27

6.2 Results regarding undeclared allergenic ingredients ...........................................27

6.3 HACCP control....................................................................................................29

6.4 Precautionary allergen labelling (PAL) ...........................................................30

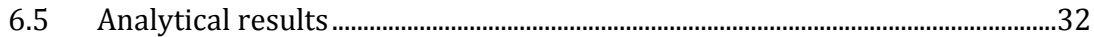

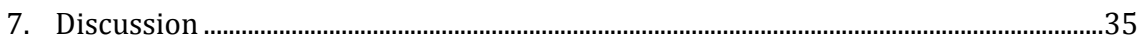

7.1 Labelling of allergenic ingredients........................................................................35

7.2 Allergen handling.....................................................................................................36

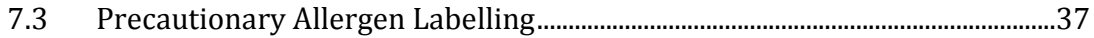

7.4 Risk for allergic and celiac consumers ..................................................................38

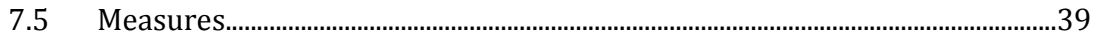

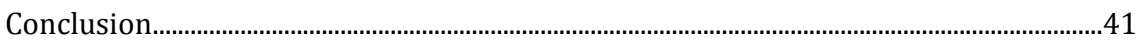

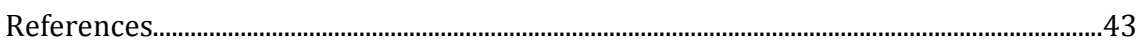

Sammanfattning: "Odeklarerade allergener i mat - livsmedelskontroll, analyser och

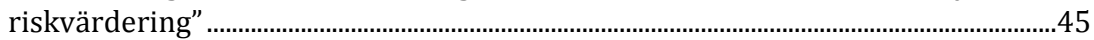

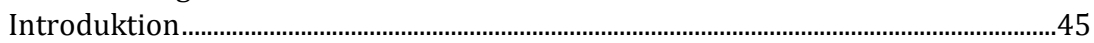

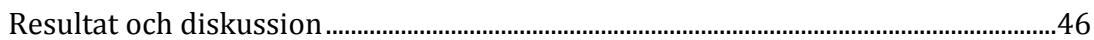


Appendix 1: Checklist for control

Appendix 2: Risk assessment regarding undeclared milk, hazelnut, peanut, egg and gluten based on results from the project Undeclared allergens in food................... 53 Introduction and hazard identification........................................................................ 53

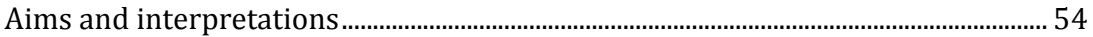

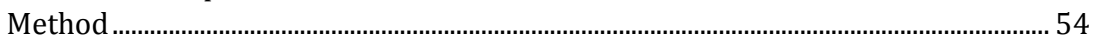

Undeclared milk protein (casein) ................................................................................ 55

Exposure assessment........................................................................................................ 56

Hazard characterization...................................................................................................... 59

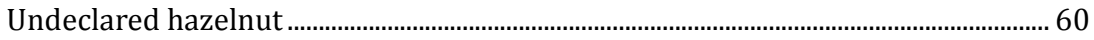

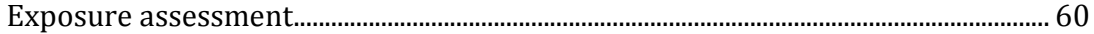

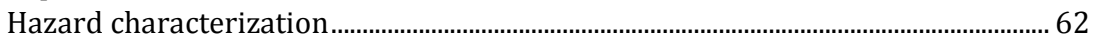

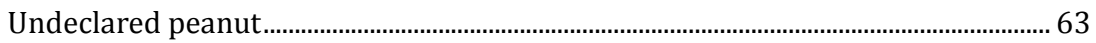

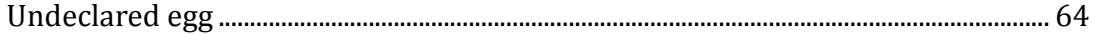

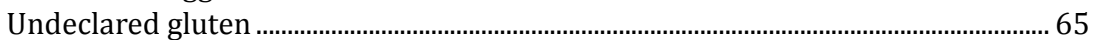

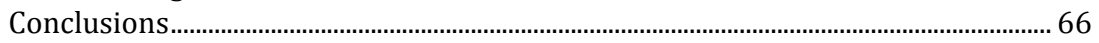

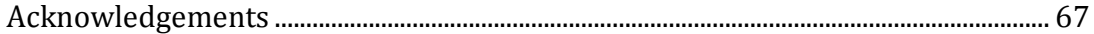

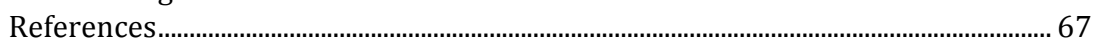

Appendix 3: Products with undeclared allergens, divided by country ........................... 69 


\section{Summary}

\section{Introduction}

During the autumn of 2015, control authorities in Denmark, Finland, Norway, and Sweden performed allergen control, including sampling, on companies producing and importing pre-packed chocolate/candy, bakery products, ready-made meals, and meat and fish products. In total 351 products were checked. These products were analysed for the allergens milk protein (casein), egg-white protein, hazelnut, peanut and gluten when these were not declared as ingredients. The project was coordinated by The National Food Agency in Sweden and was partly funded by the Nordic Working Group for Food Safety and Consumer Information within the Nordic Council of Ministers.

Allergens are substances that cause allergic reactions or other hypersensitivity reactions. The labelling of allergens is the only aid for consumers with allergies or other hypersensitivities to avoid products that could be harmful to them. Inadequate labelling of allergenic ingredients such as milk, egg, and various nuts poses a serious health risk for these consumers. Common symptoms of an allergic reaction are stomach pain, vomiting, eczema, asthma, and life-threatening anaphylactic shock.

Requirements for the labelling of allergenic ingredients are regulated by Regulation (EU) No 1169/2011 (the FIC Regulation), ${ }^{1}$ which has been in force since 13 December 2014. It is the responsibility of FBOs to only place correctly labelled products on the market. Several companies also label products with Precautionary Allergen Labelling (PAL) in order to inform allergic consumers that the product might contain allergens through contamination. This labelling is not yet regulated; however, it should not be misleading and the food business operators should also consider allergens as hazards and therefore implement and maintain procedures based on the HACCP principles (Regulation (EC) No 852/2004).2 Misleading PAL might decrease the

\footnotetext{
${ }^{1}$ Regulation (EU) No 1169/2011 of the European Parliament and of the Council of 25th October 2011 on the provision of food information to consumers.

${ }^{2}$ Regulation (EC) No 852/2004 of the European Parliament and of the Council of 29th April 2004 on the hygiene of foodstuffs.
} 
number of products available for allergic consumers and could also pose a risk because allergic consumers might ignore the labelling. In 2012, Nordic criteria for PAL were developed as part of a project showing that allergen labelling was insufficient on every fifth product and that the PAL was misleading on approximately every third product (1).

The current project aims to increase the knowledge regarding correct and accurate labelling of allergens both among food business operators and the control authorities. The project should contribute to correctly labelled products and should assist the control authorities in performing risk-based control. The results from the project should also increase the overall awareness of whether the regulations regarding allergenic ingredients are being followed. Testing for milk, egg, hazelnut, peanut, and gluten was performed in order to show the frequencies and concentrations at which undeclared allergens occur and to calculate the risk that allergic and celiac consumers are exposed to.

The product categories and allergens for analysis were chosen on the basis of risk. The control was performed with a checklist developed by the project group. Several different food inspectors from the four countries participated within the project.

\section{Results and discussion}

Allergenic ingredients were not correctly labelled on $10 \%$ of the controlled products. There were different reasons for the labelling being considered non-compliant with the FIC regulations, and all such mislabelling could have severe consequences. For example, on $3.2 \%$ of the products the list of ingredients did not match the recipe. It is the responsibility of the food business operators to ensure that products are accurately labelled because inadequate labelling of allergenic ingredients such as milk, egg, and various nuts poses a serious health risk for people with food allergies or other hypersensitivities. New legislation since 13th December 2014 states that allergenic ingredients must be highlighted in the list of ingredients for products produced after 13th December 2014 (FIC regulation), but for $18 \%$ of the products the allergens were not highlighted in the list of ingredients.

Milk was commonly detected in products without any declaration of milk (12\%). These were mainly chocolate/candy and bakery products. The risk assessment (appendix 2) concludes that at least 9,000 milkallergic children and adults within the four Nordic countries are at risk to react to every fourth of the studied chocolate/candy product and every 
twentieth bakery product that does not declare milk in the list of ingredients. These are high numbers, and the Nordic control authorities basically find this to be an unacceptable risk. Therefore, it is important to communicate that milk can be just as harmful as nuts and peanut to allergic consumers. In addition, at least 7,000 hazelnut-allergic individuals within the four countries are at risk to react to $4 \%$ of the studied chocolate/bakery products that do not declare hazelnut as an ingredient.

Milk, peanut, and hazelnut were more commonly detected in products labelled with PAL compared to products without PAL. Certain chocolate products contained milk, hazelnut and peanut in concentrations that more than $50 \%$ of the allergic consumers would react to. Allergic consumers might therefore need to avoid chocolate products with PAL for milk, hazelnut and peanut. It is also important to consider whether companies can do more to decrease the risk of contamination with allergens. There was no difference in the occurrence of egg or gluten in products labelled with or without PAL. According to the analysed products in this project, it is difficult to interpret what this means for consumers with celiac disease and other allergies regarding consumption of products with PAL.

The Nordic control authorities regard allergens as hazards, but $12 \%$ of the controlled companies had not included allergens in their hazard analyses. This indicates that some food business operators do not consider allergens to be the potential hazard that they are to allergic and celiac consumers and thus to a considerable proportion of the population.

The most common wording of the PAL was "May contain traces of (allergen)" (73\%). Eighty-nine percent of the companies assessed that contamination with the allergen was impossible to avoid in the production process. However, $35 \%$ did not identify the allergens that might appear sporadically in the products or on the production line. This indicates that some food business operators have no risk-based approach for investigating whether contaminating allergens actually can occur in their products.

The results of our analysis show that some companies did not follow the legislation regarding labelling of allergenic ingredients. The companies are responsible for accurate labelling of their products, and to achieve this they must have appropriate procedures in place and must consider allergens to be the hazard that they are. This applies especially to companies that are handling several different ingredients, of which some are also common allergens. Control authorities are responsible for ensuring compliance with the regulatory framework concerning allergen 
labelling and handling, and consumers with allergies and other hypersensitivities are responsible for reviewing the labelling and avoiding products that contain the allergens that they are sensitive to. All stakeholders benefit if regulations regarding a risk based and not misleading PAL were developed. This labelling should never be used as an excuse for unhygienic procedures. 


\section{Background}

Allergens are substances that commonly cause allergic reactions or other hypersensitivity reactions. The labeling of allergens is the only aid for consumers with allergies or other hypersensitivities, to avoid products which could cause disease. Approximately 4-6\% of the population in Europe has some form of food allergy (2). Food allergy is especially common among small children. In addition, approximately 1$2 \%$ of the population in northern Europe has celiac disease (3). Inadequate labelling of allergenic ingredients such as milk, egg, and various nuts poses a serious health risk for these consumers. Symptoms of an allergic reaction can affect several different organs, and common symptoms are stomach pain, vomiting, eczema, and asthma. Lifethreatening anaphylactic shock can also occur (further emphasized in appendix 2).

Requirements for the labelling of allergenic ingredients are regulated by Regulation (EU) No 1169/2011 (the FIC Regulation), which has been in force since 13th December 2014. A food for which an allergen ingredient is not declared is classified to be unsafe pursuant to Article 14.3 b of Regulation (EC) No 178/2002. ${ }^{3}$

Warning labelling for contamination with allergens is not yet regulated, but it must not be misleading. This labelling is often described as Precautionary Allergen Labelling (PAL). Unnecessary PAL might lead otherwise acceptable food products to be unavailable to allergic consumers and might also pose a risk if it leads allergic consumers to ignore the labelling (4). Article 36.3 in the FIC Regulation requires the EU Commission to adopt rules on the voluntary labelling of any intentional or accidental presence of substances that can cause allergies or intolerances, i.e. PAL. However, no time frame for the implementation of such rules has been set.

A Nordic report "The labelling of allergens and 'may contain allergens"' was published in 2012 (1) and presented two main findings. First, every fifth product tested was non-compliant in the labelling of

${ }^{3}$ Regulation (EC) No 178/2002 laying down the general principles and requirements of food law, establishing the European Food Safety Authority, and laying down procedures in matters of food safety (General Food Law). 
allergenic ingredients, and second, many companies labelled their products with PAL even though it was not needed. The Nordic report of 2012, held a Nordic position for the labelling of "may contain traces of (allergen)".

The project reported here aims to increase our knowledge of the correct and non-misleading labelling of allergens. The control work included companies that produce and/or import various types of prepackaged ready-made meals, bakery products, meat and fish products, and chocolate/candy. These types of products were selected because they most frequently cause unexpected allergic reactions (5). The project is an integrated Nordic control project that is partly funded by the Nordic Council of Ministers. The results from the project will be used as an input to create EU legislation regarding the use of PAL. Control authorities from Denmark, Finland, Norway, and Sweden have participated in the project, and the project has been led by the National Food Agency in Sweden. 


\section{Objectives}

This project's aim is to increase our knowledge of correct and nonmisleading labelling of allergens. The project's specific objectives are:

- to allow consumers with allergies and other hypersensitivities to make informed choices from a varied and adequate number of food products

- to increase the overall awareness of whether the regulations regarding allergenic ingredients are being followed

- to ensure that food business operators label food correctly regarding the content of allergenic ingredients. Increased knowledge regarding the labelling and handling of allergens among food business operators and control authorities should lead to correctly labelled products concerning allergenic ingredients and to an effective and risk-based system for food control

- to investigate if undeclared allergens (milk, egg, hazelnut, peanut, and gluten) are present, and if so how often and in what concentrations. The potential risk these undeclared allergens constitute will be calculated (Appendix 2)

- to give input to develop EU legislation regarding the use of Precautionary Allergen Labelling (PAL). The project will investigate the compliance of PAL with the Nordic criteria for such labelling. 



\section{Organisation}

A Nordic project group was set up to work with overall planning and organization of the project (Table 1). The project group developed the checklist to be used during the food control (appendix 1) and also developed a guidance document regarding the food control. They also coordinated the food control (5.1 Food Control). The food control was performed in each Nordic country by several different food inspectors, and all of the analyses of food allergens were performed at the National Food Agency in Sweden.

Table 1: Project organisation

Name and workplace

Project manager: Ylva Sjögren Bolin, The National Food Agency (Sweden)

Project group: Lisbet V. Nordly and Pernille Madsen, The Danish Veterinary and Food Administration (Denmark) Minna Anthoni, Finnish Food Safety Authority Evira (Finland)

Anne Bueso, Norwegian Food Safety Authority (Norway)

Ulla Fäger, The National Food Agency (Sweden)

Ingrid Lindeberg, The National Food Agency (Sweden)

Ann-Christine Larsson Ekström, the Nordic Working Group for Food Safety and Consumer Information/Nordic Council of Ministers 



\section{Legal basis}

The legal basis for this control project comes mainly from the following regulations:

- Regulation (EU) No 1169/2011 of the European Parliament and of the Council of 25th October 2011 on the provision of food information to consumers (hereinafter, the "FIC Regulation").

- The FIC Regulation sets labelling requirements for allergens (Articles 9, 12, 13 and 21). The substances or products causing allergies or intolerances, which have to be labelled in the list of ingredients, are listed in Annex II.

- Regulation (EC) No 178/2002 of the European Parliament and of the Council of 28th January 2002 laying down the general principles and requirements of food law, establishing the European Food Safety Authority, and laying down procedures in matters of food safety (General Food Law).

- This Regulation sets food safety requirements (Article 14).

- The Standing Committee on the Food Chain and Animal Health has provided a guidance document stating that if essential information on the use of food is not supplied or is incorrect then this could render the food unsafe. Article 14.3(b) states that consideration will be made with regard to the information provided to the consumer, including information on the label or other available information about avoidance of specific adverse health effects from a particular category of foods. An example of this would be where a food or a food ingredient might pose a risk to the health of a specific group of consumers in the case where mandatory information about that food or one of its ingredients was not effectively communicated.

- Regulation (EC) No 852/2004 of the European Parliament and of the Council of 29th April 2004 on the hygiene of foodstuffs.

- Food business operators shall put in place, implement, and maintain a permanent procedure or procedures based on the HACCP principles. This includes identifying any hazards 
(including allergens) that must be prevented, eliminated, or reduced to acceptable levels.

- Regulation (EC) No 882/2004 of the European Parliament and of the Council of 29th April 2004 on official controls performed to ensure the verification of compliance with feed and food law, animal health, and animal welfare rules.

- The competent authority shall designate laboratories to carry out the analysis of samples taken during official controls.

However, competent authorities may only designate laboratories that operate and are assessed and accredited in accordance with some specific European standards, e.g. ISO 17025.

\subsection{Labelling of ingredients}

The list of ingredients shall be headed or preceded by a suitable heading that consists of or includes the word "ingredients". It shall include all the ingredients of the food in descending order of weight (Article 18 the FIC Regulation). The definition of an ingredient is any substance or product, including flavourings, food additives and food enzymes - and any constituent of a compound ingredient - that is used in the manufacture or preparation of a food and is still present in the finished product, even if in an altered form; residues shall not be considered as "ingredients" (Article $2.2 \mathrm{f}$ the FIC Regulation).

It is mandatory to indicate in the labelling any ingredient or processing aid listed in Annex II in the FIC Regulation, or derived from a substance or product listed in Annex II (Table 2), used in the manufacture or preparation of a food that can cause allergies or intolerances and is still present in the finished product, even if in an altered form. 
Table 2: Allergens listed in Annex II to the FIC Regulation

Annex II to FIC Regulation: Substances or products causing allergies or intolerances

Cereals containing gluten, namely: wheat, rye, barley, oats, spelt, kamut or their hybridised strains, and products thereof

2. Crustaceans and products thereof

3. Eggs and products thereof

4. Fish and products thereof

5. Peanuts and products thereof

6. Soybeans and products thereof

7. Milk and products thereof (including lactose)

8. Nuts, namely: almonds, hazelnuts, walnuts, cashews, pecan nuts, Brazil nuts, pistachio nuts, macadamia/Queensland nuts, and products thereof

9. Celery and products thereof

10. Mustard and products thereof

11. Sesame seeds and products thereof

12. Sulphur dioxide and sulphites at concentrations of more than $10 \mathrm{mg} / \mathrm{kg}$ or $10 \mathrm{mg} / \mathrm{litre}$ in terms of the total $\mathrm{SO}_{2}$ levels that are to be calculated for products that are proposed to be ready for consumption or as reconstituted according to the instructions of the manufacturers

13. Lupin and products thereof

14. Molluscs and products thereof

Note: There are a few exceptions of substances listed in Annex II in the FIC Regulation that do not have to be labelled as allergens.

According to Article 21 in the FIC Regulation, the allergens shall be indicated in the list of ingredients in accordance with the rules laid down in Article 18(1) with a clear reference to the name of the substance or product as listed in Annex II. The name of the substance or product as listed in Annex II shall also be emphasized through a typeset that clearly distinguishes it from the rest of the list of ingredients, for example, by means of the font, style, or background colour. For example, these might be written as wheatstarch or starch (WHEAT) and casein (milk) or casein (MILK).

Allergenic ingredients shall be declared when included as:

- Ingredients: Namely raw materials as well as additives and flavourings. 
- Compound ingredients: Allergens in a compound ingredient shall be declared. For instance, the list of ingredients for a bun with a vanilla filling could be written as: "Wheat flower, vanilla filling 20\% (water, sugar, modified starch, milk powder, vegetable fat (coconut), natural vanilla flavour), skimmed milk, sugar, vegetable oil (rapeseed), egg, water, yeast, salt". See Part E, Annex VII in the FIC Regulation for compound ingredients.

- Category of food: "Crumbs" is an example of a designation of a category of food. If wheat or egg are ingredients in bread crumbs, they shall be declared, for instance, as "crumbs (wheat, egg)". See Part B, Annex VII in the FIC Regulation for designation of category of food.

- Additives: This also includes additives that do not have a function in the final product (carry over) and carriers. Soy lecithin is an example of an additive prepared from an allergen, and wheat and milk proteins can be used as carriers in spices.

- Processing aids: These are intentionally used in the processing of food and might result in unintentional but technically unavoidable presence in the final product.

Food business operators at all stages of production, processing, and distribution within the business under their control shall ensure that foods satisfy the requirements of food laws which are relevant to their activities and shall verify that such requirements are met. See Article 17 in Regulation (EC) No 178/2002.

\subsection{Precautionary Allergen Labelling, hygiene, and the responsibility of the food business operator}

Food business operators shall put in place, implement, and maintain a permanent procedure or procedures based on the HACCP principles. This includes identifying any hazards that must be prevented, eliminated, or reduced to acceptable levels (See Article 5 in Regulation (EC) No 852/2004). Allergens should be included as a hazard when relevant. Labelling a product with PAL, without using HACCP principles, is an incorrect measure with regard to preventing, eliminating, or reducing the risk with an allergen.

The FIC Regulation does not yet regulate the use of the term "may contain traces of..." or other precautionary allergen labelling that is used by food business operators to warn consumers of unintentional contamination. However, according to Article 36.3 in the FIC Regulation, 
the Commission shall adopt implementing acts on the application of the requirements for voluntary information regarding the possible and unintentional presence in food of substances or products causing allergies or intolerances ("may contain traces of..."). No implementing acts on this subject have yet been adopted.

Voluntary information, such as "may contain traces of...," should not be used in a way that could mislead the consumer (See Article 36.2 in the FIC Regulation). Article 7.1 (c) in the FIC Regulation states that food information shall not be misleading, especially by suggesting that the food possesses special characteristics when in fact all similar foods possess such characteristics or by specifically emphasizing the presence or absence of certain ingredients and/or nutrients. This article may depending on the individual case, be used when the labelling with "may contain traces of..." is used despite the fact that repeated analyses do not find any presence of the allergen. It is important to investigate why the food business operator has used PAL in such as case, and the Nordic position might be helpful in determining this.

\subsubsection{The Nordic position from 2012 (1)}

A label that highlights the risk of contamination should never be used as an excuse for poor hygiene and insufficient control procedures. If procedures are missing or not properly applied, the expression "may contain traces of ..." is not helpful to the consumer. This can result in the consumer either taking a risk by eating the product or being forced to avoid a product that might not cause problems.

Precautionary allergen labelling should only be a final option when the risk of contamination with allergens on a specific production line is:

1. Uncontrollable, i.e. it is impossible to control the entire production process.

a. e.g. part of the production equipment is not accessible for cleaning or cannot be cleaned with water.

2. Sporadically occurring, i.e. identified through e.g.

a. analysis of an allergen that is homogeneously distributed in the product

b. visible parts/shavings on the production equipment even after cleaning

c. through inspection of the cleaning process

d. verified allergic reaction in consumers. 
Other precautionary allergen labelling than "may contain traces of (allergen)" is not recommended because it is difficult for an allergic consumer to understand the meaning of the warning labels if several types are used.

\section{Conditions for importers or introducers of food}

The importer must ensure that the producing company can show that the allergens listed on the advisory labelling comply with the conditions presented above for use of the "May contain traces of (allergen)" label. This can be done e.g. through documentation or by an inspection of the manufacturing premises by the importer. 


\section{Food control, sampling, and analysis of food allergens}

\subsection{Food control}

Food control is organized differently in Sweden, Finland, Denmark, and Norway. The food control in Norway and Denmark is performed on a national level whereas in Sweden and Finland the food control is performed mostly locally but also on a national level. For this project, Norway and Denmark decided to exert food control on approximately 100 products each. In Sweden and Finland local control authorities were encouraged to participate in the project, but it could not be decided in advance how many products would be controlled in the countries. Table 4 in section 6.1 shows how many products were controlled in each country.

The controlled companies, the sampling procedures, and the allergens selected for analysis were chosen in a risk-based manner, including:

- Companies producing and importing pre-packed chocolate/candy, bakery products, meat/fish products, and ready-made meals.

- Products that a person allergic to milk, egg, peanut, or hazelnut or intolerant to gluten would likely choose based on such products not containing one or more of those allergens according to the list of ingredients.

- Products labelled with warnings for contamination with milk, egg, peanut, hazelnut, or gluten.

- One to five products from each controlled food business operator were chosen for control and analysed for the presence of milk protein, egg, peanut, hazelnut, and/or gluten.

The project did not include:

- Products labelled "gluten-free", "milk-free", etc.

- Foods packed on the business's premises at the consumer's request or prepacked for direct sale. 
- Analyses of other allergens than milk protein, egg, peanut, hazelnut, or gluten.

- The compiling of data on the measures taken after non-compliance with the legislation was detected. It is the responsibility of the food business operator to follow the legislation, and it is the responsibility of the control authority to follow up on such cases.

The food inspectors were provided with a checklist for control (appendix 1) and a guide to the checklist. The checklist included questions to be answered, and the guide included background information, the text of the relevant legislation, and explanations of various terms. In addition, a note of delivery was provided that was to be filled in for the laboratory performing the analysis.

The food control was partly performed in Sweden and Denmark during 24 August to 18th September 2015. All countries also performed food control from 19th October to 13th November 2015. The data from the food controls were thereafter reported through an electronic reporting system provided by the Swedish National Food Agency. The results from these food controls are described in section 6 .

\subsection{Sampling}

Currently no harmonized protocol exists for sampling foods for the analysis of food allergens. It was therefore agreed among the participating agencies that the overall results from the analyses would be sufficient if at least 300 products were analysed. One sealed sample from each product was sent to the laboratory at the Swedish National Food Agency, one sealed sample was saved by the control authority, and one sealed sample was offered to the food business operator. If further analyses were to be needed, these samples could be analysed within official control. The sample should consist of at least $30 \mathrm{~g}$ of product, and thus a sample of 3 pieces of chocolate at $10 \mathrm{~g}$ each could constitute one sample. On the delivery note to the laboratory, the food inspectors filled in which allergens the product should be analysed for. The products were analysed for the allergens that were not declared in the list of ingredients, including casein (milk protein), hazelnut, peanut, egg-white protein, and gluten. These allergens were chosen because allergies to milk, hazelnut, peanut, and egg are the most common food allergies in the Nordic countries. Additionally, celiac disease (gluten intolerance) is common in the Nordic countries (Appendix 2). 


\subsection{Analysis of food allergens}

The National Food Agency in Sweden (NFA) is accredited according to the ISO Standard 17025 to perform analyses of certain food allergens in certain food matrices. Only accredited laboratories can perform analyses within official food control (Regulation (EC) No 882/2004). ${ }^{4}$ Casein (milk protein), hazelnut, peanut, egg-white protein, and gluten are among the allergens that the NFA is accredited to analyse in compound food products. Table 3 provides details of the methods that were used. All methods are based on commercially available Enzyme Linked Immunosorbent Assays (ELISAs). These ELISAs have been further validated by the NFA to meet the criteria for the analysis of food allergens in the relevant food matrices set by the laboratory. In-house reference materials are extracted and analysed as a sample during each analysis. Currently no standard methods for analyses of food allergens are available. Because certain steps regarding extraction and analysis with some of the ELISA test kits have been modified by the laboratory, the names of the test kits are not provided here.

The first step of the analysis was to make a homogenous sample out of each sample. For samples weighing $30 \mathrm{~g}$ to $250 \mathrm{~g}$, the whole sample was mixed, melted, or ground based on the sample matrix. For samples weighing 250-500 g, half of the sample was mixed, melted, or ground. For products weighing more than $500 \mathrm{~g}$, only a quarter of the sample was mixed, melted, or ground. The samples were weighed in tubes and extracted with the relevant extraction buffer. The extraction buffer was different for all allergens except for peanut and egg-white protein, which used the same buffer. The same extract could thus be used in the peanut and egg-white protein ELISAs.

Two products each that were analysed for casein, egg-white protein and peanut contained concentrations of allergens that were above the limit of detection (LOD) but below the limit of quantification (LOQ) of each method. These samples were given a concentration value between the LOD and LOQ in the calculations, i.e. $2.0 \mathrm{mg}$ casein $/ \mathrm{kg}, 0.4 \mathrm{mg}$ eggwhite protein $/ \mathrm{kg}$, and $0.7 \mathrm{mg}$ peanut $/ \mathrm{kg}$.

${ }^{4}$ Regulation (EC) No 882/2004 on official controls performed to ensure the verification of compliance with feed and food law, animal health, and animal welfare rules. 
Table 3: Performance criteria of the methods used

\begin{tabular}{|c|c|c|c|c|c|}
\hline & $\begin{array}{l}\text { Casein (Milk } \\
\text { protein) }\end{array}$ & $\begin{array}{l}\text { Egg-white } \\
\text { protein }\end{array}$ & Gluten & Peanut & Hazelnut \\
\hline $\begin{array}{l}\text { Limit of } \\
\text { quantifycation } \\
\text { (LOQ) }\end{array}$ & $\begin{array}{l}2.5 \mathrm{mg} \\
\text { casein/kg }\end{array}$ & $\begin{array}{l}0.5 \mathrm{mg} \text { egg- } \\
\text { white } \\
\text { protein } / \mathrm{kg}\end{array}$ & $5 \mathrm{mg}$ gluten $/ \mathrm{kg}$ & $1 \mathrm{mg}$ peanut $/ \mathrm{kg}$ & $\begin{array}{l}2.5 \mathrm{mg} \\
\text { hazelnut } / \mathrm{kg}\end{array}$ \\
\hline $\begin{array}{l}\text { Limit of } \\
\text { detection (LOD) }\end{array}$ & $\begin{array}{l}1.4 \mathrm{mg} \\
\text { casein/kg }\end{array}$ & $\begin{array}{l}0.3 \mathrm{mg} \text { egg- } \\
\text { white } \\
\text { protein } / \mathrm{kg}\end{array}$ & $3 \mathrm{mg}$ gluten $/ \mathrm{kg}$ & $0.5 \mathrm{mg}$ peanut $/ \mathrm{kg}$ & $\begin{array}{l}1.5 \mathrm{mg} \\
\text { hazelnut } / \mathrm{kg}\end{array}$ \\
\hline Specificity & & & $\begin{array}{l}\text { Detects gluten } \\
\text { from wheat, } \\
\text { rye, and barley } \\
\text { but not from } \\
\text { oat. }\end{array}$ & $\begin{array}{l}\text { The method can } \\
\text { give false positive } \\
\text { results in } \\
\text { products that } \\
\text { contain high } \\
\text { concentrations of } \\
\text { soy protein }\end{array}$ & \\
\hline $\begin{array}{l}\text { Measurement } \\
\text { uncertainty }\end{array}$ & $45 \%$ & $50 \%$ & $35 \%$ & $35 \%$ & $30 \%$ \\
\hline
\end{tabular}

Source: $\quad \mathrm{a}=$ This was controlled for by studying the list of ingredients. In one product, a low concentration of peanut was detected and the product also contained soy. The cross reactivity was therefore mentioned in the analytical report.

\subsection{Statistics}

Statistical comparison of products labelled with and without PAL regarding the frequencies of products with detectable allergens (casein, hazelnut, peanut, gluten, and egg-white protein) was performed with the $\chi^{2}$ test. $p<0.05$ was considered a significant difference. 


\section{Results}

\subsection{Results regarding controlled companies}

In total, information regarding food control of 339 products was imported into the electronic reporting system. Products were controlled and sampled in Denmark, Finland, Norway and Sweden (Table 4), and most products were produced in the country in which the control was performed. Some products were imported from one of the four Nordic countries and controlled in the importing Nordic country. Thus more products were produced in Finland (35 products) compared to controlled in Finland (33 products). Fifty products were imported from other countries within the EU other than Denmark, Finland, and Sweden. Nine products were produced in other countries outside the EU other than Norway.

A total of 256 products (76\%) were controlled at producing companies, 74 products were controlled at importing companies, and 9 products had no information about whether they were from an importing or a producing company.

Table 4: Country in which the products were controlled and produced

\begin{tabular}{lrr} 
Country & Products controlled in & Products produced in \\
Denmark & 78 & 52 \\
Finland & 33 & 35 \\
Norway & 97 & 79 \\
Sweden & 131 & 109 \\
Other country within EU & - & 50 \\
Other country outside EU & - & 9 \\
Not stated & - & 5 \\
\hline
\end{tabular}

The large majority (91\%) of the controls were performed together with a company representative who had quality-assurance responsibilities.

\subsection{Results regarding undeclared allergenic ingredients}

For 34 of the 339 products (10\%), the allergenic ingredients were not correctly transcribed in the list of ingredients and therefore did not 
follow the FIC Regulation. For products labelled by importing companies, the allergenic ingredients were not correctly transcribed on $11 \%$ of the products.

Figure 1: Reasons explaining why labelling of allergenic ingredients was considered non-compliant with the FIC Regulations

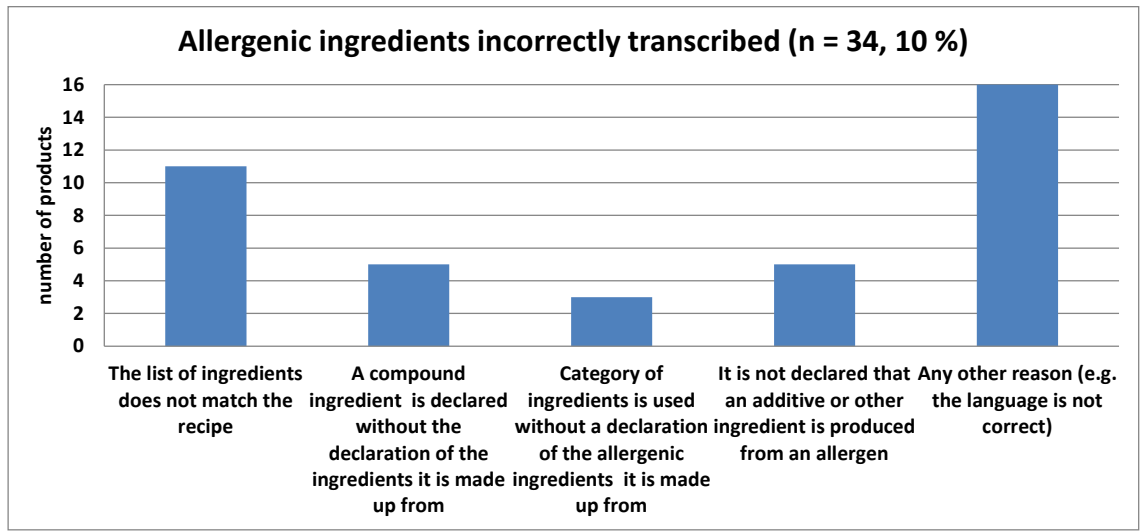

The reasons for why the labelling of allergens was considered noncompliant are shown in Figure 1. On 11 products, the list of ingredients did not match the recipe (3.2\%). On eight products $(2.4 \%)$, a compound ingredient (e.g. vanilla cream) or a category of ingredient (e.g. bread crumbs) was used without a declaration of the allergens that these contain. On five products $(1.5 \%)$, it was not declared that an additive was produced from an allergen, e.g. that lecithin was made from soy. The most common reason for why the labelling of allergenic ingredients was considered non-compliant was "Any other reason, e.g. the language was not correct". This was the case for 16 products (4.7\%). For six of these products, this alternative was chosen due to the allergens not being highlighted in the list of ingredients. This was not a correct alternative because this question was a later question (see below). However, it cannot be ruled out that there were also other reasons for the labelling of allergens to be considered non-compliant regarding these six products.

In Figure 2, the eight allergens that were not correctly transcribed, according to the control at the premises, are presented. Allergens that often occur as ingredients (egg, milk, and gluten-containing grains) were among the allergens that most commonly were not transcribed. Also, nuts and soy were among the allergens that most commonly were undeclared. Celery, mustard, and fish were not declared in one product each. 
Figure 2: Allergenic ingredients that were not transcribed in the list of ingredients

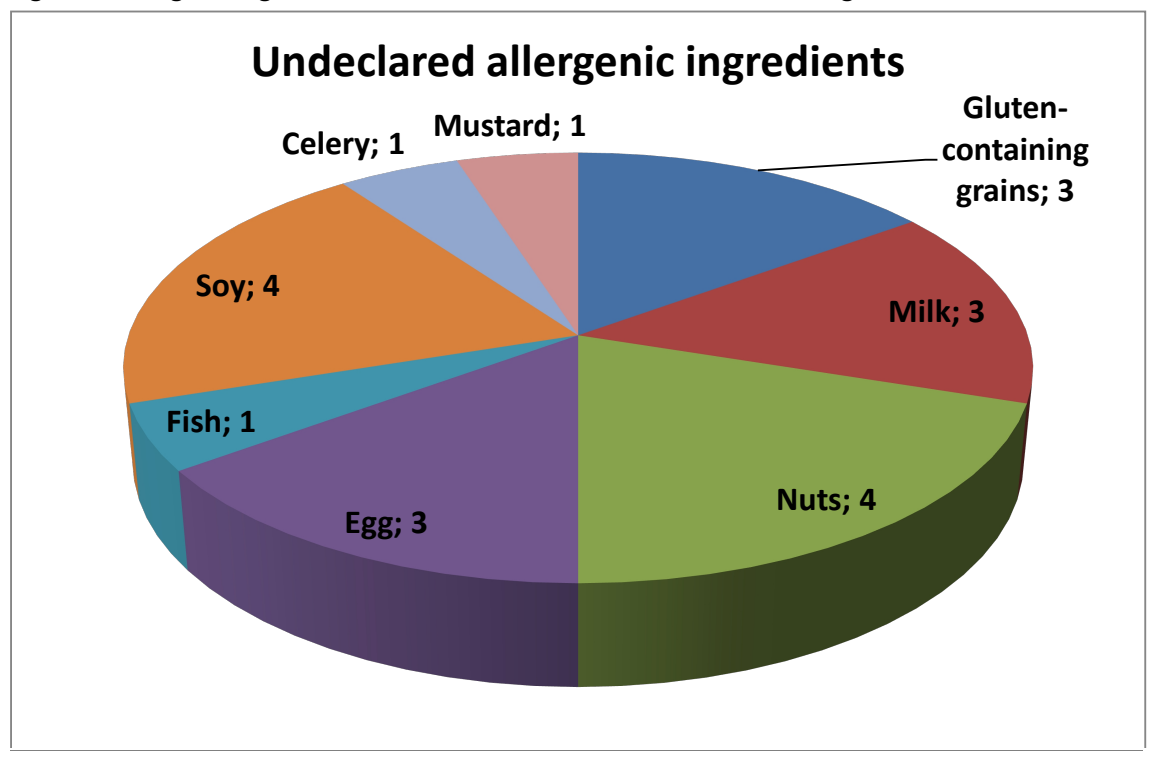

Note: The numbers describe the number of products with undeclared allergens.

The food inspectors also investigated whether the allergens were highlighted in the ingredients list, e.g. in bold font. This legislation only applies to products produced after 13 December 2014. For $18 \%$ of the products, the allergens were not highlighted in the list of ingredients.

\subsection{HACCP control}

The Nordic food control authorities regard allergens as hazards that food business operators should perform a hazard analysis for when allergens can potentially occur at their premises ((EC) no 852/2004). A total of $12 \%$ of the companies controlled in this project that should include allergens in their HAACP had not done so (table 5). Of the $69 \%$ of companies that had included allergens in their HAACP, about one third of the HAACP were not judged to be applicable by the food inspector. However, only 55 products were controlled for if the HAACP was applicable and the above presented data is thus made from a small number of results compared to the other results. In most companies the allergen HAACP was known by the personnel (controlled on 49 products). The hazard analyses in the production of the product is not relevant for importing companies but the importing company still must ensure the accuracy of the labels. The food inspectors chose the 
alternative "Importing company - not relevant" for $13 \%$ of the products regarding whether the company had included allergens in their HACCP. Most companies had an action plan for recalls (94\%).

\begin{tabular}{|c|c|c|c|c|}
\hline $\begin{array}{l}\text { Handling of allergens included } \\
\text { in the hazard analysis? }\end{array}$ & Numbers & $\%$ & $\begin{array}{r}\% \text { of the Allergen } \\
\text { Hazard analyses that } \\
\text { were judged applicable }\end{array}$ & $\begin{array}{r}\% \text { of personnel aware } \\
\text { of the Allergen } \\
\text { Hazard analysis }\end{array}$ \\
\hline Yes & 234 & 69 & 64 & 90 \\
\hline No & 39 & 12 & & \\
\hline $\begin{array}{l}\text { No handling of allergens at the } \\
\text { company }\end{array}$ & 8 & 2.3 & & \\
\hline Importing company (not relevant) & 45 & 13 & & \\
\hline Not stated & 13 & 3.8 & & \\
\hline
\end{tabular}

\subsection{Precautionary allergen labelling (PAL)}

In total, 130 products were labelled with some form of PAL warning for contamination with allergens. Chocolate/candy was the product group that most often was labelled with PAL (73\% of the products) (figure 3). Almost every other bakery product was labelled with PAL (43\%). Nine and eight percent, respectively, of meat/fish products and ready-made meals were labelled with PAL.

Figure 3: The total number of products controlled in the project within each product category and with or without precautionary allergen labelling (PAL)

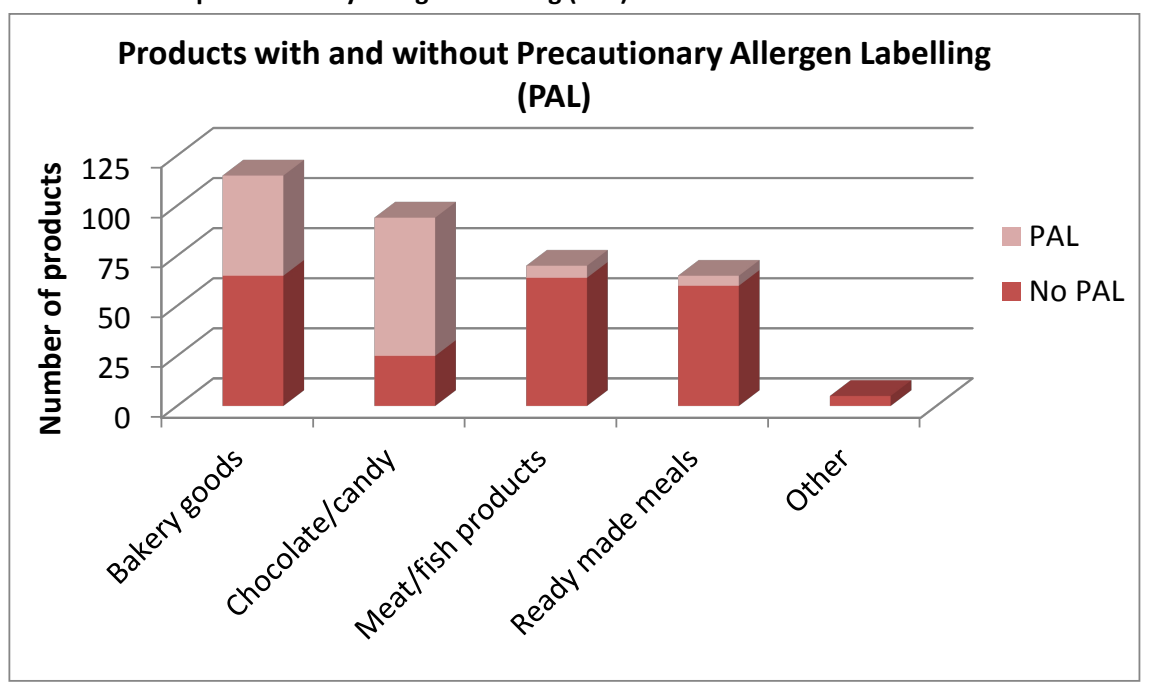


The most common PAL was a "warning" for nuts $35 \%$ of the PAL products) (Figure 4), either for certain specified nuts or more generally with the term "nuts. The Nordic food control authorities feel that each nut in the PAL should be specified, and this is also consistent with the Commission's position. PAL was also used for milk (16\% of products), gluten-containing grains (13\% of products), peanut ( $10 \%$ of products), and egg ( $7 \%$ of products). The PAL also warned for other allergens $(19 \%$ of products) for which the specific allergen was not recorded in the electronic reporting system.

For about half of the products that were labelled with PAL, it was determined whether the companies followed the Nordic criteria for labelling products with PAL. The wording was "May contain traces of (allergen)" on 73\% of the products. Most companies (89\%) assessed that contamination with the allergen was impossible to avoid in the production process (Table 6). The allergen had been identified sporadically in the products and/or on the production line in $65 \%$ of the products. These figures are in line with the percentage of companies that were aware of the Nordic criteria for labelling products with PAL (68\%). Of the 35\% of the companies that had not identified the allergen in the products or on the production line, approximately $25 \%$ were not aware of the Nordic criteria. However, $75 \%$ were aware of the Nordic criteria but had not investigated whether the allergens occurred sporadically in the product.

Figure 4: The allergens that the Precautionary Allergen Labelling

\section{Which allergens does the PAL constitue?}

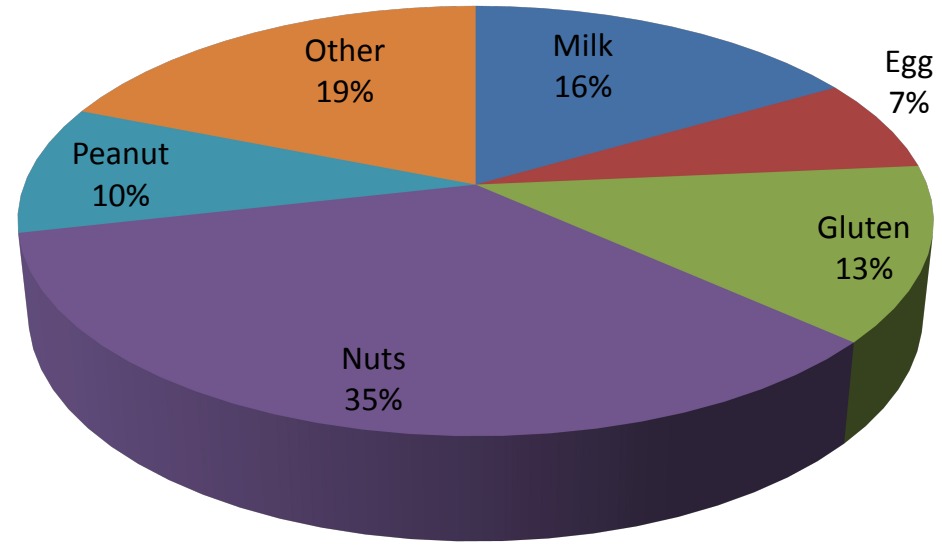


Table 6: Questions regarding whether the food business operators follow and are aware of the Nordic criteria for labelling products with “May contain traces of...

\begin{tabular}{|c|c|c|}
\hline & Yes (\% responders) & No (\% responders) \\
\hline $\begin{array}{l}\text { Does the company assess that contamination with the } \\
\text { allergen is impossible to avoid in the production process }\end{array}$ & 64 (89\%) & $8(11 \%)$ \\
\hline $\begin{array}{l}\text { Has the allergen been identified sporadically in the products } \\
\text { and/or on the production line? }\end{array}$ & $42(65 \%)$ & $23(35 \%)$ \\
\hline $\begin{array}{l}\text { Is the company aware of the Nordic criteriaa for labelling } \\
\text { products with "May contain traces of..."? }\end{array}$ & $206(68 \%)$ & $98(32 \%)$ \\
\hline
\end{tabular}

Source: $\quad a=$ In Sweden, these are incorporated in the Swedish food sector guidelines (6).

It was also investigated whether there was a difference in the awareness of the Nordic criteria in the different countries (Table 7) because the approach to spreading the Nordic criteria has been a little different in the different countries. The awareness, of the criteria, was lowest in Sweden and Denmark.

Table 7: Questions regarding whether the company is aware of the Nordic criteria for labelling products with "May contain traces of..." divided according to country

\begin{tabular}{|c|c|c|c|}
\hline $\begin{array}{l}\text { Is the company aware of the Nordic criteriaa for } \\
\text { labelling products with "May contain traces of..."? }\end{array}$ & Yes (\%) & No (\%) & Not stated (\%) \\
\hline Denmark & $56(72 \%)$ & $12(15 \%)$ & $10(13 \%)$ \\
\hline Finland & 24 (73\%) & $1(3 \%)$ & $8(24 \%)$ \\
\hline Norway & 57 (59\%) & 40 (41\%) & 0 \\
\hline Sweden & 69 (53\%) & 45 (34\%) & $17(13 \%)$ \\
\hline
\end{tabular}

\subsection{Analytical results}

A total of 1,193 analyses for food allergens were performed on 351 products. These were the products that control results also were reported for, however for 12 products no control asresult was reported. Table 8 shows how many analyses were performed for each allergen. As stated in section 5.2, each product should be analysed for the allergens that were not declared in the list of ingredients, and products should be analysed for the allergens that were specifically mentioned in the PAL. Products were analysed for one to five allergens according to how many of the allergenic ingredients milk, egg, peanut, hazelnut, and glutencontaining grains were not part of the product's ingredients list. For each product, the food inspector and the food business operator received an analytical report describing the analyses performed, the 
analytical methods used, the results, and the measurement uncertainty of the methods.

A total of $51 \%$ of products labelled with PAL for milk contained casein above the LOD. The range was quite wide $(2.7-8,800 \mathrm{mg}$ casein $/ \mathrm{kg}$ ), and a significantly greater number of products labelled with PAL for milk contained milk compared with products without PAL (statistically significant). However, $12 \%$ of the products without PAL for milk contained milk. These were mainly products within the product categories of chocolate/candy and bakery products (Appendix 2). For hazelnut and peanut, it was also significantly more common that PAL products contained the allergen (statistically significant). The range of allergen concentrations was also immense for these products (the range for hazelnut was $3.1-18,500 \mathrm{ppm}$, and for peanuts the range was $0.7-42,500 \mathrm{ppm}$ ). For egg-white protein and gluten, there were no significant differences in allergen occurrence between products labelled with and without PAL. In the risk assessment, it is discussed what risk these allergens constitute for the allergic consumers (Appendix 2).

Table 8: Analytical results divided according to allergen and according to whether the products were labelled with or without Precautionary Allergen Labelling (PAL)

\begin{tabular}{|c|c|c|c|c|c|c|}
\hline \multirow[t]{2}{*}{ Allergen } & \multirow[t]{2}{*}{$\begin{array}{l}\text { Analysed } \\
\text { products }\end{array}$} & \multicolumn{2}{|c|}{$\begin{array}{l}\text { Undeclared allergen in products } \\
\text { with PAL (concentration range) }\end{array}$} & \multicolumn{2}{|c|}{$\begin{array}{l}\text { Undeclared allergen in products } \\
\text { without PAL (concentration range) }\end{array}$} & \multirow[t]{2}{*}{ p-value } \\
\hline & & Number & $\%$ & Number & $\%$ & \\
\hline $\begin{array}{l}\text { Casein } \\
\text { (Milk protein) }\end{array}$ & 176 & $\begin{array}{l}21 \text { out of } 41 \\
\text { (range } 2.7-8,800 \mathrm{ppm} \text { ) }\end{array}$ & $51 \%$ & $\begin{array}{l}16 \text { out of } 135 \\
\text { (range } 2.0-2,600 \mathrm{ppm} \text { ) }\end{array}$ & $12 \%$ & $<0.001$ \\
\hline Hazelnut & 299 & $\begin{array}{l}14 \text { out of } 93^{a} \\
\text { (range } 3.1-18,500 \mathrm{ppm} \\
\text { ) }\end{array}$ & $15 \%$ & $\begin{array}{l}4 \text { out } 206 \\
\text { (range } 31-130 \mathrm{ppm} \text { ) }\end{array}$ & $1.9 \%$ & $<0.001$ \\
\hline Peanut & 292 & $\begin{array}{l}5 \text { out of } 29 \\
\text { (range } 0.7-42,500 \mathrm{ppm} \text { ) }\end{array}$ & $17 \%$ & $\begin{array}{l}3 \text { out } 263 \\
\text { (range } 0.7-2.8 \mathrm{ppm} \text { ) }\end{array}$ & $1.1 \%$ & $<0.001$ \\
\hline $\begin{array}{l}\text { Egg-white } \\
\text { protein }\end{array}$ & 259 & $\begin{array}{l}1 \text { out of } 14 \\
(27 \mathrm{ppm})\end{array}$ & $7.1 \%$ & $\begin{array}{l}5 \text { out of } 245 \\
\text { (range } 0.4-550 \mathrm{ppm} \text { ) }\end{array}$ & $1.9 \%$ & n.s. \\
\hline Gluten & 167 & $\begin{array}{l}1 \text { out of } 30^{b} \\
(6.4 \mathrm{ppm})\end{array}$ & $3.3 \%$ & $\begin{array}{l}6 \text { out of } 137 \\
\text { (range } 6.6-27 \mathrm{ppm} \text { ) }\end{array}$ & $4.4 \%$ & n.s. \\
\hline $\begin{array}{l}a=\operatorname{Prc} \\
b=\operatorname{Prc} \\
\text { n.s. }=1 \\
\text { The lin } \\
\text { ppm }=\end{array}$ & $\begin{array}{l}\text { cts labelle } \\
\text { significant labelle } \\
\text { of detectio } \\
\mathrm{g} / \mathrm{kg}\end{array}$ & $\begin{array}{l}\text { ith PAL for hazelnut or fo } \\
\text { ith PAL for gluten, wheat } \\
\text { and limit of quantification }\end{array}$ & $\begin{array}{l}\text { "nuts". } \\
\text { or othe } \\
\text { f the d }\end{array}$ & $\begin{array}{l}\text { uten-containing grains. } \\
\text { rent methods are describ }\end{array}$ & nders & 6.3. \\
\hline
\end{tabular}





\section{Discussion}

\subsection{Labelling of allergenic ingredients}

Ingredients that are listed in Annex II of the FIC regulation should be declared in the list of ingredients. However, for $10 \%$ of the controlled products the allergenic ingredients were not correctly transcribed in the list of ingredients. The list of ingredients on a product is the only aid for consumers with allergies and other hypersensitivities in order for them to avoid foods with allergens. Of most concern were the results showing that the list of ingredients in many cases did not match the recipe and that a compound ingredient (e.g. vanilla cream) or a category of ingredient (e.g. bread crumbs) was used without a declaration of the allergens that these contained. The allergic consumers cannot make an informed choice and thus avoid the product when the allergenic ingredients are not transcribed at all. The analysis presented here shows that these ingredients can occur in high enough concentrations to be hazardous to allergic consumers. For egg and hazelnut, the highest concentrations measured (550 mg egg-white protein/kg and 18,500 mg hazelnut $/ \mathrm{kg}$ ) were from products in which the allergenic ingredients were not correctly transcribed. The hazelnut-containing chocolate was labelled with PAL for hazelnut, but such labelling cannot replace the proper labelling of allergenic ingredients.

On five products, it was not declared that an additive was produced from an allergen, e.g. that the lecithin in the product was made from soy. This example can also constitute a risk for allergic consumers; however, the risk is probably lower because the amount of allergenic protein is lower in a product that contains an additive made from an allergen compared to if it contains the allergenic ingredient itself. Allergens that are very common as ingredients, e.g. milk, gluten-containing grains, and egg, were among the allergenic ingredients that were most commonly not declared in the list of ingredients.

In the Nordic control project "Allergen labelling and the use of advisory labelling 'May contain traces of (allergen)'” (1) conducted in 2011, the allergen labelling in the ingredient list was found to be unsatisfactory for $20 \%$ of the controlled products. The result from the current project thus shows a decrease, which might be the result of 
measures taken by the food business operators and the control authorities during the years between the two analyses. However, it is difficult to fully compare the results of the two analyses because the questions were asked a bit differently in this project and because additional product categories were controlled for in the previous project.

On 18\% of the products, the allergens were not highlighted in the list of ingredients. This allergen labelling legislation is new and applies to products produced after 13th December 2014 (FIC regulation). When the controls were performed during the autumn of 2015, at least eight to eleven months had passed since the new legislation entered into force. However, products controlled within the project could have been produced before 13th December 2014, and thus the allergens would not have needed to be highlighted on the products. This was emphasized in the guidance document provided to the control authorities participating in the project and those products should not have been included in the figures. If the allergens are not highlighted, this might pose a risk for allergic consumers if they only look for highlighted ingredients. Labelling with highlighted ingredients also makes it easier for the consumer to find the allergens in the list of ingredients. It is therefore important that the food business operators follow the new legislation and ensure that products placed on the market are in compliance with food safety requirements (Art. 19 General Food Law).

In 2015 the Norwegian Food Safety Authority performed a control regarding labelling on meat and meat products (7). Their analysis showed that allergens were not correctly transcribed on $47 \%$ of the products. The reasons for non-compliance were e.g. that the allergens were not highlighted in the list of ingredients, that the product contained the allergen but that it was not transcribed in the list of ingredients, or that the product contained several different labellings regarding the allergen.

\subsection{Allergen handling}

The Nordic control authorities regard allergens as hazards that must be prevented, eliminated, or reduced to acceptable levels. Food business operators must put in place a permanent procedure based on the HACCP principle (Regulation (EC) no 852/2004), but $12 \%$ of the food business operators had not included allergens in their HACCP. This might correlate with the observation, that the allergenic ingredients were not 
correctly transcribed in the list of ingredients on $10 \%$ of the products. Additionally, it might also explain the observation that undeclared allergens were found in products without PAL. Thus, it is of great importance that FBO's are thorough when conducting their risk analysis regarding allergens in the final product. The food inspectors found that the allergen hazard analysis provided by the food business operator was only applicable in $64 \%$ of the investigations, and this low number might also explain some of the other results we have obtained during this project. If labelling is not seen as a Good Manufacturing Procedure by the food business operator, there might be mistakes in the labelling of allergenic ingredients.

\subsection{Precautionary Allergen Labelling}

The most common wording for PAL was "May contain traces of (allergen)", and this was stated on 73\% of the products with PAL. This is similar to the results of the previous Nordic project (1). According to the Nordic criteria for PAL, this is the only wording that should be used. When the other criteria were investigated, it was found that most companies (89\%) determined that contamination with the allergen was impossible to avoid. However, $35 \%$ of these companies had not actually identified any sporadically occurring allergens in their products or production lines. Accurate assessment of the actual presence of allergens is an important measure in order to avoid misleading PAL. Remarkably, almost $75 \%$ of these companies were aware of the Nordic criteria for labelling products with PAL but still labelled products without first identifying the presence of allergens in the products or on the production line. This shows the need for regulation regarding riskbased PAL. In Sweden, the Nordic criteria have been incorporated into the Food Sector Guidelines (6), but it was actually in Sweden that the awareness of the criteria was the lowest.

The analyses showed that it was more common that products labelled with PAL for milk, peanut, and hazelnut (or nuts) contained the allergen compared with products without such labelling. This could be interpreted that the PAL is relevant for these products, and this could be important information for allergic consumers. However, it should always be ensured that a certain food business operator actually follows the Nordic criteria, especially if they sporadically identify the allergen on the production line or in the products. Also it should be determined whether it is possible to avoid or reduce allergen contamination through proper 
cleaning and other measures. The high concentration of allergens found in certain products labelled with PAL for milk, peanut, and hazelnut could be indications that the cleaning of the production line was not sufficient. The high concentrations of allergens were mainly detected in chocolate products, and it is often reported that cleaning with water is difficult in chocolate manufacturing due to microbial growth. Still, it is the responsibility of the food business operator to find good methods and procedures/routines to decrease allergenic contamination.

The analyses of egg-white protein and gluten showed that there were no differences in the occurrence of egg and gluten in products labelled with and without PAL. The result for egg is similar to the results found in an American study (8). However, milk was more commonly found in products with PAL in our study compared to the American study. The difference regarding milk might be explained by the high proportion of chocolate products that were analysed in our project because dark chocolate products are often labelled with PAL for milk. A study from the Food Standards Agency also shows that milk often occurs in products from the confectionary category (9). Differences in sampling and analytical methods could also account for the difference. Interestingly, peanut was more common in products with PAL compared to without PAL, both in our study and in the American study. Regarding peanuts and nuts, these are often considered as allergens that contaminate products in a heterogeneous/particulate manner due to the allergens occurring in discrete pieces. The sampling procedure would thus be especially important regarding peanut and nut analyses.

\subsection{Risk for allergic and celiac consumers}

According to our analyses, milk protein was more common in products labelled with PAL (51\%) compared with products without the labelling $(12 \%)$. However, it is very concerning that $12 \%$ of the products contained milk without any information that the product contains the allergen either as an ingredient or through contamination. In Appendix 2 , a risk assessment concluded that more than 9,000 milk-allergic children and adults within the four Nordic countries are at risk to react to every fourth of the studied chocolate/candy product and every twentieth bakery product that do not declare milk in their lists of ingredients. These are high numbers, and the Nordic control authorities basically find this to be an unacceptable risk. In addition, at least 7,000 hazelnut allergic individuals within the four Nordic countries are at risk 
to react to $4 \%$ of the studied chocolate/bakery products. The reactions could vary from mild oral allergy syndrome to severe asthma, vomiting, and life-threatening anaphylactic shock. A risk assessment was performed on analytical data from the study by the Food Standards Agency (10), and that analysis showed that up to $50 \%$ of milk allergic individuals might react to dark chocolate. Also, up to $11 \%$ of hazelnutallergic consumers might react to chocolate (including dark chocolate, milk chocolate, and chocolate spread). Our risk assessment concluded that there were certain chocolate products with PAL for milk, hazelnut and peanut that could constitute a risk for more than $50 \%$ of those allergic to these allergens.

The highest risk was for undeclared milk. One potential explanation for this might be that food business operators are more aware of allergenic risks with peanuts and nuts and thus consider milk to be a lower risk. It is important to communicate that severe allergic reactions can occur to milk protein and that this allergy is especially common among small children. Milk is also a very common food ingredient, and there is a higher risk that common food ingredients will occur in products either as an undeclared ingredient or through contamination compared to ingredients that are less common.

\subsection{Measures}

At all stages of production, processing, and distribution within the business under their control, food business operators shall ensure that foods satisfy the requirements of food law that are relevant to their activities and shall verify that such requirements are met (Article 17 in Regulation (EC) No 178/2002). This project shows that the food business operators do not always follow the legislation and thus expose allergic consumers to unnecessary risk. This applies especially to producers of chocolate/candy and bakery products. This report does not include the follow up of food business operators that were found to be non-compliant in their product labelling, and it is the responsibility of each control authority to perform such follow-ups. Additionally, control authorities are responsible for ensuring compliance with the regulatory framework for allergen labelling and allergen handling. Based on the results reported here, we would recommend that it may therefore be appropriate with more frequent control for facilities producing chocolate/candy and bakery products in order for the food control to be risk-based. 
Article 36.3 in the FIC Regulation requires the Commission to adopt rules on the voluntary labelling of any unavoidable or accidental presence of substances that can cause allergies or intolerances, i.e. "may contain traces of ..." labelling. However, no time frame has been set for adopting such rules. In the Nordic report of 2012 (1), a Nordic position was developed for the labelling of "may contain traces of (allergen)", and the current project further shows the need for regulations regarding PAL. It is of great importance to the allergic consumer that EU legislation be developed regarding contamination and precautionary allergen labelling because harmonized risk-based legislation on PAL would lead to safer food for the allergic consumer. 


\section{Conclusion}

- Inadequate labelling of allergenic ingredients such as milk, egg, and various nuts poses a serious health risk for people with food allergies or other hypersensitivities. We found that allergenic ingredients were not correctly transcribed on $10 \%$ of the controlled products. The food business operator is responsible for ensuring that products are accurately labelled and that they have functioning internal control for allergen safety.

- Milk was commonly detected in products without any declaration of milk (12\%). These were mainly chocolate/candy and bakery products. The risk assessment concludes that at least 9,000 milkallergic children and adults within the four Nordic countries are at risk to react to every fourth of the studied chocolate/candy product and every twentieth bakery product that does not declare milk in the list of ingredients. These are high numbers, and the Nordic control authorities basically find this to be an unacceptable risk. Therefore, it is important to communicate that milk can be just as harmful as nuts and peanut to allergic consumers. In addition, at least 7,000 hazelnut-allergic individuals within the four Nordic countries are at risk to react to $4 \%$ of the studied chocolate/bakery products.

- Labelling warning for contamination with allergens (Precautionary Allergen Labelling (PAL)) is not yet regulated. The labelling should, however, not be misleading. Milk, peanut, and hazelnut were more commonly detected in products labelled with PAL compared to products without PAL. Certain chocolate products contained milk, hazelnut and peanut in concentrations that more than $50 \%$ of the allergic consumers would react to. Allergic consumers might therefore need to avoid chocolate products with PAL for milk, hazelnut and peanut. There was no difference in the occurrence of egg or gluten in products labelled with or without PAL. According to this project, it is difficult to interpret what this means for consumers with celiac disease and other allergies regarding consumption of products with PAL.

- The most common wording for PAL was "May contain traces of (allergen)" (73\% of products with PAL). A total of $89 \%$ of the companies assessed that contamination with the allergen was 
impossible to avoid in the production process. However, $35 \%$ of the companies using PAL had not actually identified the allergen sporadically in the products or on the production line. This indicates that some food business operators have no risk-based approach for investigating whether or not the allergens actually occur in their products. The Nordic control authorities therefore see the need for legislation for PAL.

- The Nordic control authorities regard allergens as hazards. The food categories controlled (chocolate/candy, bakery products, meat/fish products, ready-made meals) were chosen on the basis of risk, i.e. they were food categories that often contain different allergens. We found that $12 \%$ of the companies had not included allergens in their hazard analyses, which indicates that some food business operators do not sufficiently take into consideration the threat that allergens pose to allergic and celiac consumers.

- Allergenic ingredients should be highlighted in the list of ingredients. This legislation is new and applies to products produced after 13th December 2014 (FIC regulation). On 18\% of the products tested, the allergens were not highlighted in the list of ingredients. The food business operator is responsible for ensuring that products are accurately labelled. 


\section{References}

1. Nordic Council of Ministers (2012). The labeling of allergens and "may contain allergens". www.norden.org/en/publications

2. Opinion of the Scientific Panel on Dietetic Products, Nutrition and Allergies on a request from the Commission relating to the evaluation of allergenic foods for labelling purposes. EFSA Journal 2004;32:1-197.

3. Di Sabatino A and Corazza GR. Coeliac disease. Lancet 2009;373:1480-93. http://dx.doi.org/10.1016/S0140-6736(09)60254-3

4. Study on the impact of food information on consumers' decision making. TNS European Studies Consortium. December 2014.

http://ec.europa.eu/food/safety/docs/labelling_legislation_study_food-info-vscons-decision_2014.pdf

5. Ferm $M$ and Sjögren Y. Milk, the most commonly undeclared food allergen causing unexpected allergic reactions in Sweden 2004-2011. www.slv.se

6. Swedish Food Sector Guidelines For: - Management and labelling of food products with reference to Allergy and Intolerance English version, August 2005. Revised version in Swedish June 2015.

7. Mattilsynet. Merkesjekken (2015). Mattilsynet ser på kjøtt og kjøttprodukter.http:// www.mattilsynet.no/mat_og_vann/merking_av_mat/generelle_krav_til_merking_av_ mat/merkesjekken_2015_kjott_og_kjottprodukter.21012/binary/Merkesjekken\%20 2015:\%20Kj\%C3\%B8tt\%20og\%20kj\%C3\%B8ttprodukter

8. Ford LS et al. Food allergen advisory labelling and product contamination with egg, milk and peanut. J Allergy Clin Immunol 2010;126:34-5. http://dx.doi.org/ 10.1016/j.jaci.2010.05.034

9. Hirst B. (2014) Reading Scientific Services LTD. Survey of allergen advisory labelling and allergen content of UK retail pre-packed processed foods. www.fsa.uk.

10. Remington BC et al. Unintended allergens in precautionary labelled and unlabelled products pose significant risks to UK allergic consumers. Allergy 2015;70:813-19. http://dx.doi.org/10.1111/all.12625 



\section{Sammanfattning: "Odeklarerade allergener i mat - livsmedelskontroll, analyser och riskvärdering"}

\section{Introduktion}

Under hösten 2015 genomförde livsmedelsinspektörer i Danmark, Finland, Norge och Sverige kontroller på livsmedelsföretag i ett samordnat nordiskt projekt. Märkning och hantering av allergener som mjölk, ägg och olika nötter kontrollerades. De företag som ingick var producenter och importörer av färdigförpackad choklad, godis, bageriprodukter samt hel- och halvfabrikat. Totalt kontrollerades 351 produkter. I kontrollen ingick även provtagning och analys av allergenerna mjölk, hasselnöt, jordnöt, ägg och/eller gluten i de produkter som inte angav dessa som ingredienser. Sådan analys syftade till att visa om dessa allergener förekommer $\mathrm{i}$ livsmedlen. Kontamination och att allergena ingredienser inte anges kan vara anledningar till att de finns i livsmedlen. Projektet leddes av Livsmedelsverket och finansierades delvis av Nordiska ministerrådet.

Allergener är ämnen, vanligtvis proteiner, som orsakar allergiska reaktioner eller andra överkänslighetsreaktioner. Korrekt märkning är det enda sättet för allergiker att undvika det de inte tål och på så sätt att förhindra allergiska reaktioner. Allergiker kan reagera med olika symtom och kan få såväl magont, kräkningar och eksem som astma och allergisk (anafylaktisk) chock. En allergisk chock kan vara livshotande.

Märkning av allergena ingredienser regleras av Förordning (EU) $\mathrm{Nr}$ 1169/2011 (Informationsförordningen) 5 som ska tillämpas från 13 december 2014. Livsmedelsföretag märker ibland produkter med frivillig märkning för att varna allergiker för att produkten kan ha kontaminerats med allergener under produktionen. Sådan

${ }^{5}$ Europaparlamentet och rådets förordning (EU) nr 1169/2011 av den 25 oktober 2011 om tillhandahållande av livsmedelsinformation till konsumenterna. 
varningsmärkning är ännu inte reglerad, men den får inte vara vilseledande. Företagen ska också betrakta allergener som faror och därför ha rutiner baserade på s.k. HACCP för att minimera dessa faror (Förordning (EG) Nr 852/2004). ${ }^{6}$ Vilseledande varningsmärkning kan minska utbudet för allergiker och innebära en risk genom att allergiker chansar på att de tål produkten. Under 2012 togs en nordisk hållning fram med kriterier för varningsmärkning för allergener. Detta genomfördes inom ett kontrollprojekt ${ }^{7}$ som visade att allergena ingredienser inte angavs korrekt på var femte produkt och att varningsmärkningen ansågs vilseledande på var tredje produkt.

Syftet med projektet har varit att öka kännedomen, hos livsmedelsföretag och kontrollmyndigheter, om korrekt och redlig märkning av allergena ingredienser. Projektets mål är att bidra till att produkter är korrekt märkta gällande allergena ingredienser och även till en riskbaserad kontroll. Resultaten från projektet ska också öka kännedomen om huruvida lagstiftningen om allergener och märkning följs samt i vilken utsträckning mjölk, hasselnöt, jordnöt, ägg och gluten förekommer odeklarerade i livsmedel. Analysresultaten gör det möjligt att uppskatta vilken risk vissa allergiker och glutenintoleranta är utsatta för. De produkttyper som ingick och de allergener som var utvalda för analys med ackrediterade metoder, valdes utifrån att de oftast orsakar oväntade allergiska reaktioner. ${ }^{8}$ Kontrollen utfördes av flera olika livsmedelsinspektörer från de fyra länderna med hjälp av en checklista och en vägledning som togs fram inom projektet.

\section{Resultat och diskussion}

På $10 \%$ av de kontrollerade produkterna angavs inte allergena ingredienser korrekt utifrån regler i Informationsförordningen. Anledningarna till att reglerna inte följdes var flera och kan ge upphov till allvarliga reaktioner hos allergiker och andra överkänsliga. Exempelvis stämde inte recept- och ingrediensförteckning överens på 3,2 \% av produkterna. Företagen ansvarar för att följa livsmedelslagstiftningen och se till att märkningen är korrekt. Även ny lagstiftning, som måste tillämpas

\footnotetext{
${ }^{6}$ Europaparlamentet och rådets förordning (EG) nr 852/2004 av den 29th April 2004 om livsmedelshygien. ${ }^{7}$ Nordiska ministerrådet 2012. The labeling of allergens and "may contain allergens". www.norden.org/en/publications

${ }^{8}$ Ferm M. and Sjögren Y. Milk, the most commonly undeclared food allergen causing unexpected allergic reactions in Sweden 2004-2011. www.slv.se
} 
sedan 13 december 2014, om att allergena ingredienser som mjölk, ägg och olika nötter särskilt ska framhävas i ingrediensförteckningen undersöktes. På nästan var femte produkt var allergenerna inte framhävda i ingrediensförteckningen.

Mjölkprotein påvisades i $12 \%$ av de produkter där mjölk varken angavs som ingrediens eller där det förekom varningsmärkning för kontamination med mjölk. Detta var särskilt choklad- och bageriprodukter. Riskvärderingen visar att fler än 9000 mjölkallergiska barn och vuxna inom de fyra länderna riskerar att reagera på var fjärde undersökt chokladprodukt och var tjugonde undersökt bageriprodukt som inte anger mjölk i ingrediensförteckningen. De nordiska kontrollmyndigheterna anser att dessa höga siffror är oacceptabla. Det är därför viktigt att tydliggöra att mjölk kan orsaka lika allvarliga reaktioner som jordnöt och nötter. Riskvärderingen visar också att fler än 7000 hasselnötsallergiker inom de fyra nordiska länderna riskerar att reagera på var tjugofemte undersökt choklad-/bageriprodukt som inte anger hasselnöt i ingrediensförteckningen.

Mjölkprotein, hasselnöt och jordnöt förekom oftare i produkter som var varningsmärkta med dessa allergener jämfört med produkter utan varningsmärkningen. Vissa chokladprodukter innehöll mycket höga koncentrationer mjölkprotein, hasselnöt och jordnöt som skulle kunna orsaka reaktioner hos fler än hälften av allergikerna. Allergiska konsumenter kan därför behöva undvika chokladprodukter med varningsmärning för mjölk, nötter och jordnötter. Producenterna bör göra mer för att sänka halterna allergen som orsakas av kontamination. Äggviteprotein och gluten förekom i ungefär samma utsträckning i varningsmärkta som i ej varningsmärkta produkter. Utifrån dessa analysresultat går det inte att tolka vad detta betyder för personer med celiaki och andra allergier gällande konsumtion av varningsmärkta produkter.

De nordiska kontrollmyndigheterna klassar allergener som faror och därför ska företagen ha rutiner för att reducera förekomsten av kontamination med allergener. $12 \%$ av företagen hade dock inte inkluderat allergener i sin faroanalys. Detta kan vara en indikation på att vissa företag inte förstår vilken risk de kan utsätta allergiker och andra överkänsliga för.

Den vanligaste varningsmärkningen för kontamination med allergener var "Kan innehålla spår av (allergen)" vilket angavs på $73 \%$ av de 130 produkter som hade varningsmärkning. De flesta av de företag som använde varningsmärkning (89\%) ansåg att det var omöjligt att undvika kontamination med allergener. Dock hade en tredjedel av dessa 
företag inte sporadiskt påvisat allergenet i produkten eller på produktionslinjen. Det tyder på att flera företag inte baserar själva varningsmärkningen på en faktisk risk för kontamination.

Sammanfattningsvis visar resultaten att vissa producenter och importörer inte följer lagstiftningen om märkning av allergener. Detta trots att det är företagens ansvar. För att klara detta måste företagen betrakta allergener som en fara och ha fungerande rutiner, vilket inte heller var något som företagen alltid hade. Särskilt viktigt är det att företag som hanterar vanliga ingredienser som mjölk, ägg, vete och nötter har dessa rutiner och är medvetna om att allergenerna innebär en fara. Kontrollmyndigheterna är ansvariga för att granska att företagen följer lagstiftningen om märkning och hantering. Konsumenter med allergi och annan överkänslighet har ansvar för att titta på märkningen men de ska kunna lita på att märkningen är rätt. Företag, kontrollmyndigheter och konsumenter skulle vinna på en lagstiftning om varningsmärkning för allergener som är riskbaserad och inte vilseledande. En sådan märkning ska inte vara en ursäkt för att företag inte har tillräckliga rutiner för att undvika kontaminering. 


\section{Appendix 1: Checklist for control}

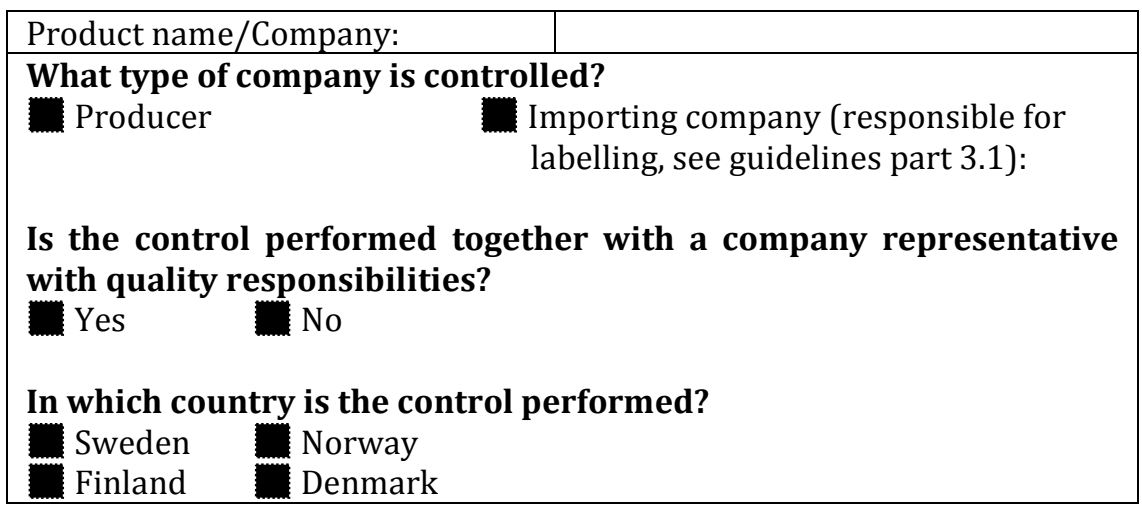

Product to control

1.0 Mark which of the following product categories the pre-packed
product constitute:
Chocolate, candy
Bakery goods (bread, buns, cookies, crisp bread etc.)
Meat and fish products (meatballs, sausages, pâté etc.)
Ready-made meals (lasagna, casserole, soup, meatballs with mashed
potatoes)

1.1 Where is the product produced?

Sweden

Norway

Finland Denmark

Other country within EU

Other country outside EU

Control of labelling of allergens

2.0 Are the allergenic ingredients correctly transcribed in the list of ingredients?

Regulation (EU) nr 1169/2011, articles 9, 12, 13, 21 and Annex II (Food information regulation)

Yes (continue with 3.0) No

The product does not contain any of

(continue

the 14 allergens in Annex II

with 3.0) 
2.1 If No, why?

a) The list of ingredients is missing.

b) The list of ingredients does not match the recipe.

c) A compound ingredient (e.g. cake filling) is declared without the declaration of the ingredients that constitute the compound ingredient.

d) Category of ingredients (Annex VII B) is used without a declaration of the allergenic ingredients e.g. bread crumbs (without declaration of wheat).

e) It is not declared that an additive or other ingredient is produced from

an allergen (e.g. lecithin is declared but not its origin from soy or egg).

f) Any other reason (e.g. the language is not correct).

2.2 Mark which of the allergen/allergens that mistakenly are not declared in the list of ingredients (a-e):

Cereals containing gluten (e.g. wheat, rye or barley).

Milk and milk products

Nuts (almond, hazelnut, walnut, cashew, pistachio nut, pecan nut,

brazilian nut, macadamia nut/Queenslandnut

Egg

Peanut

Fish

Soy

Celery

Mustard

Sesame

Lupin

Crustaceans

Sulphur dioxid and sulphite in concentrations above $10 \mathrm{mg} / \mathrm{kg}$ or

$10 \mathrm{mg} / \mathrm{liter}$

Mollusks

3.0 Are the allergens highlighted in the list of ingredients e.g. in bold font? (art 21)

Yes No

4-6 Self-monitoring

4.0 Is handling of allergens included in the hazard analysis?

Yes (If possible continue with the optional questions) No The company does not handle any allergens The question is not relevant importing company

OPTIONAL 4.1. Do you assess that the hazard analysis of the company, regarding allergens, is applicable?

Yes No Not assessed (lack of time) Not assessed (too difficult to assess)

OPTIONAL 4.2 Is the personnel aware of the hazard analysis?

Yes No Not assessed (lack of time)




\subsection{Does the company have an action plan for recalls?}

Yes No

6. Voluntary labelling regarding cautionary labelling for allergens

6.0 Is the product labelled with cautionary labeling for allergens (e.g."may contain traces of...")

Im (answer the questions 6.1, 6.4, 6.5 and if possible 6.2-3.)

No (answer only question 6.5)

6.1 Is the wording of the cautionary labelling exactly "May contain traces of..."

Yes No

OPTIONAL 6.2 Does the company assess that contamination with the allergen is impossible to avoid in the production process? (see guidelines part $3.4,6.2$ )

Yes No Not assessed (lack of time)

OPTIONAL 6.3 Has the allergen been identified sporadically in the products and/or on the production line?

Yes No Not assessed (lack of time)

6.4 Which allergen/allergens do the cautionary labelling constitute of:

Milk

Egg

Peanut

Hazelnut (incl. "nuts")

Cereals containing gluten

Other

6.5 Is the company aware of the Nordic criteria for labelling products with "May contain traces of..."?

III Yes

No 



\title{
Appendix 2:
}

\section{Risk assessment regarding undeclared milk, hazelnut, peanut, egg and gluten based on results from the project Undeclared allergens in food}

\author{
Introduction and hazard identification
}

Food allergens are substances (often proteins) that commonly cause allergic reactions or other hypersensitivity reactions. Inadequate labelling of food allergens such as milk, egg, and different nuts can cause severe health problems for allergic individuals. The symptoms of an allergic reaction vary from mild to severe and can involve one or several organs such as the skin, the gastrointestinal tract, and the airways. The most severe symptom is anaphylactic shock, which can lead to death.

Allergic individuals show a high variability regarding both which allergic symptoms they develop as well as which dose of allergen they react to. The doses of milk, peanut, hazelnut and egg proteins that different allergic individuals react to, can vary from micrograms to grams (1). During the autumn of 2015, a Nordic food control project regarding undeclared allergens was conducted in Sweden, Denmark, Finland, and Norway. Samples of products were collected with subsequent chemical analyses of milk protein (casein), peanut, hazelnut, gluten, and egg-white protein. Simultaneously, The National Food Agency in Sweden (NFA) released a guide regarding how to assess the risk to allergic consumers if a certain food product is contaminated with milk, peanut, hazelnut, or egg (2). The purpose of the guide was to give support to food inspectors and Food Business Operators (FBOs) on how to assess the risk if undeclared allergens were found in products that were analysed during the project.

The overall results from the project are presented in the report "Undeclared allergens in food - food control, analyses and risk assessment" (referred to as "the report"). Both the results from the food control program as well as analytical results are presented in the report. 
The current risk assessment is based on the risk assessment guide (2) and covers the risk for consumers to develop allergic reactions to milk, egg, peanut and hazelnut, taking into account the overall analytical results from the project. In addition, the risk for consumers with celiac disease and wheat allergy is also presented.

\section{Aims and interpretations}

The aim of the risk assessment is to assess the risk for consumers who are allergic to milk, egg, peanut, or hazelnut based on the analytical results obtained in the project - Undeclared allergens in food. In addition, the risk for consumers with celiac disease and wheat allergy is discussed. Milk and hazelnut were commonly detected, and for these allergens exposure assessments were made. An interpretation of the exposure assessment is that the results from the project reflect the Nordic market.

\section{Method}

In total, 351 products were analysed within the project. These products belonged to the product categories: Chocolate/candy, Bakery products, Meat and fish products, and Ready-made meals. Only pre-packed products were included in the project. For each product, the food inspector and FBO received an analytical report describing the analyses that were performed, the analytical methods used, the results and the measurement uncertainty. In total, 1,193 analyses were performed (see the report section 6.5). Milk, egg, peanut, hazelnut, and/or gluten were the allergens that the products were analysed for, and products were analysed for the allergens that were not included as ingredients in the list of ingredients. The analytical methods and sampling along with the measurement uncertainties are described in the report, section 5 .

The doses of milk, peanut, hazelnut, wheat or egg proteins that allergic individuals react to, vary from micrograms to grams (1). Eliciting doses that trigger allergic reactions at the population level are often referred to as ED (2). ED01 describes the dose that triggers an allergic reaction in the most sensitive $1 \%$ of the allergic population, and ED10 describes the dose that triggers an allergic reaction in the most sensitive $10 \%$ of the allergic population. However, the EDs do not show how severe these reactions will be. 
In order to recalculate an analytical result (concentration) into the dose of the allergen that might be consumed, the amount of the food eaten at one time needs to be taken into account. This is further described in the Risk assessment guide (2) in which average portion sizes and large portion sizes (95th percentile) of certain food categories are described. These portion sizes are based on Swedish food consumption data. Each allergen is presented, and the number of products that exceed the ED01 and ED10 for each product category is presented. The large portion size is used for the calculations because this will result in an extra safety factor.

Population data from Denmark, Finland, Norway, and Sweden (Table 9) were used to calculate the number of allergic consumers at risk to react to the most commonly undeclared allergens, i.e. milk and hazelnut. These data were taken from national statistics from 2016 (5).

Table 9: Population data from the four Nordic countries below (5)

\begin{tabular}{lrrr} 
& $\mathbf{0 - 1 7}$ years & $>$ 18 years & Total \\
Denmark & $\mathbf{1 , 1 6 7 , 4 6 0}$ & & \\
Finland & $\mathbf{1 , 1 9 7 , 1 9 4}$ & $\mathbf{4 , 5 3 9 , 5 4 0}, 707,000$ \\
Norway & $\mathbf{1 , 1 2 6 , 0 0 0}$ & $\mathbf{4 , 2 9 0 , 1 1 4}$ & $5,487,308$ \\
Sweden & $\mathbf{2 , 0 2 5 , 0 7 7}$ & $4,087,985$ & $5,213,985$ \\
Total & $5,515,731$ & $7,833,717$ & $9,858,794$ \\
& & $20,751,356$ & $26,267,087$ \\
\hline
\end{tabular}

Table 10: Occurrence of milk and hazelnut allergies in Denmark, Finland, Norway and Sweden

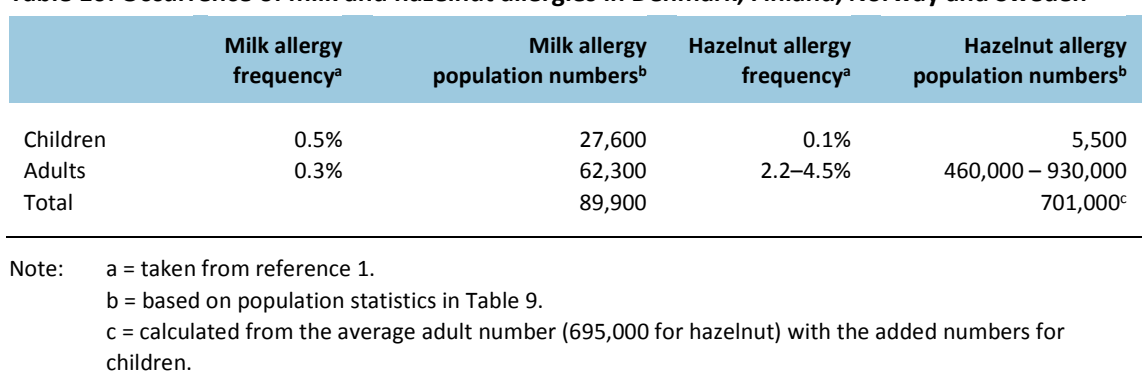

\section{Undeclared milk protein (casein)}

Casein was analysed in 176 products (Table 11) and was detected in 37 products $(21 \%)$. It was detected in $51 \%$ of the products that were labelled with Precautionary Allergen Labelling (PAL), and the range was $2.7-8,800 \mathrm{mg}$ casein $/ \mathrm{kg}$. Casein was also detected in $12 \%$ of products without PAL with a range of 2.0 to $2,600 \mathrm{mg}$ casein $/ \mathrm{kg}$. All but three products in which casein was detected were in the food categories chocolate/candy or bakery products (Table 12). 
Table 11: Casein (milk protein) detected and quantified in products with and without Precautionary Allergen Labelling (PAL)

\begin{tabular}{|c|c|c|c|c|}
\hline \multirow[t]{2}{*}{$\begin{array}{l}\text { Analysed } \\
\text { products }\end{array}$} & \multicolumn{2}{|c|}{$\begin{array}{l}\text { Undeclared casein in products with PAL } \\
\text { (range } \mathrm{mg} / \mathrm{kg} \text { ) }\end{array}$} & \multicolumn{2}{|c|}{$\begin{array}{l}\text { Undeclared casein in products without PAL } \\
\text { (range } \mathrm{mg} / \mathrm{kg} \text { ) }\end{array}$} \\
\hline & Number & $\%$ & Number & $\%$ \\
\hline 176 & $\begin{array}{l}21 \text { out of } 41 \\
\text { (range } 2.7-8,800 \mathrm{mg} / \mathrm{kg} \text { ) }\end{array}$ & $51 \%$ & $\begin{array}{l}16 \text { out of } 135 \\
\text { (range } 2.0-2,600 \mathrm{mg} / \mathrm{kg} \text { ) }\end{array}$ & $12 \%$ \\
\hline
\end{tabular}

\section{Exposure assessment}

\section{Undeclared casein - all products}

All 37 products (21\% of products analysed for casein) contained casein giving a dose above the ED01 if a large portion size is consumed. This means that more than $1 \%$ of the allergic consumers could develop an allergic reaction when consuming these products (Table 12). Consequently, every fifth product analysed within the project could be a potential risk for the most sensitive milk-allergic consumers. Of those analysed, 26 products (14\% of products analysed for milk) contained milk at concentrations that would contribute to a dose above the ED10 when the relevant portion sizes were considered. This means that every seventh product analysed within the project could cause an allergic reaction in at least $10 \%$ of the milk-allergic population. A total of 42 chocolate/candy products were analysed for milk within the project. This means that every other chocolate/candy product analysed for milk could cause a reaction in at least $10 \%$ of the milk-allergic population. Seventy bakery products were analysed for milk within the project, and thus could $6 \%$ of bakery products cause a reaction in at least $10 \%$ of the milk allergic population. 


\begin{tabular}{|c|c|c|c|c|c|c|}
\hline \multicolumn{2}{|c|}{ Food category } & $\begin{array}{r}\text { kg consumed/ } \\
\text { portion (95th } \\
\text { percentile) }\end{array}$ & $\begin{array}{r}\text { ED01 } \\
(\mathrm{mg})\end{array}$ & $\begin{array}{r}\text { Number of products } \\
\text { with a calculated } \\
\text { intake above ED01* }\end{array}$ & $\begin{array}{r}\text { ED10 } \\
(\mathrm{mg})\end{array}$ & $\begin{array}{r}\text { Number of products } \\
\text { with a calculated } \\
\text { intake above ED10* }\end{array}$ \\
\hline \multicolumn{2}{|c|}{ Chocolate/candy } & 0.138 & 0.08 & 24 & 4.0 & 22 \\
\hline \multicolumn{2}{|c|}{ Sweet bread } & 0.136 & 0.08 & 7 & 4.0 & 3 \\
\hline \multicolumn{2}{|c|}{ Soft bread } & 0.107 & 0.08 & 3 & & 1 \\
\hline \multicolumn{2}{|c|}{ Sausage } & 0.198 & 0.08 & 1 & 4.0 & 0 \\
\hline \multicolumn{2}{|c|}{ Fish finger } & 0.200 & 0.08 & 1 & 4.0 & 0 \\
\hline \multicolumn{2}{|c|}{$\begin{array}{l}\text { Potato-based } \\
\text { casserole }\end{array}$} & 0.400 & 0.08 & 1 & 4.0 & 0 \\
\hline \multicolumn{7}{|c|}{$\begin{array}{l}\text { Note: }{ }^{*} \text { The measurement uncertainty of the method was } 45 \% \text {. When the measurement uncertainty is } \\
\text { considered, one additional chocolate/candy product and one additional bakery product would be } \\
\text { included in the ED10 column because the analysed concentrations are close to the lower value that the } \\
45 \% \text { measurement uncertainty provides. Still, when the measurement uncertainty is considered, two } \\
\text { chocolate/candy products are below the higher value the } 45 \% \text { measurement uncertainty provides. }\end{array}$} \\
\hline
\end{tabular}

\section{Casein in products with precautionary labelling for milk}

The results for casein are further divided in Figure 5 according to whether the products were labelled with PAL or not. All but two of the caseincontaining chocolate products labelled with PAL contain casein giving a dose well above the ED10 when the relevant portion size is considered (15 products). There are no thresholds for labelling products with PAL; however, a report on consumers' decision-making published by the European Commission shows that approximately 25\% of allergic consumers consider products with PAL to be "safe" or "probably safe" (3). ED50 is $156 \mathrm{mg}$ milk protein according to one study (4), which equals 125 mg casein. Four of the chocolate products with PAL for milk contained casein that would result in a dose above this value if consumed in a large portion.

\section{Undeclared casein - products without precautionary allergen labelling}

All of the 7 casein-containing chocolate products without PAL contained casein giving a dose well above the ED10 when the relevant portion size is considered. In total, 42 chocolate/candy products were analysed for casein. Thus, $17 \%$ of the analysed chocolate/candy products contained undeclared casein (and no PAL for milk) at concentrations that would result in a dose that more than $10 \%$ of the milk-allergic consumers would react to. 
Figure 5: Undeclared casein (milk protein) in products with and without Precautionary Allergen Labelling (PAL)

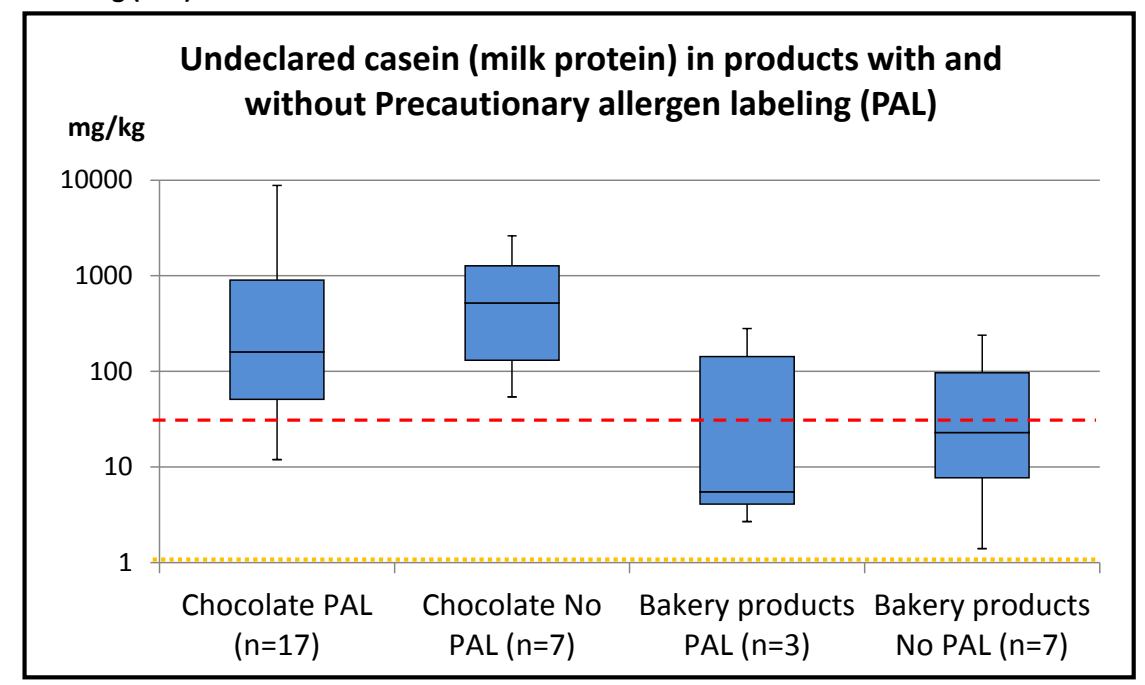

Note: The dotted yellow line and the red dashed line indicate the concentrations of casein in chocolate and bakery products that would contribute to a dose causing reactions in $1 \%$ (ED01) (....) and 10\% (ED10) (- - -) of the milk-allergic population, respectively, when portion sizes of chocolate and bakery products are considered.

Approximately $1 \%$ of children $0-4$ years of age are allergic to milk (1). When the child population is described as children 0-17 years, the prevalence is approximately $0.5 \%$. This corresponds to approximately 27,600 children within the four Nordic countries (Table 10).

If at least $10 \%$ in this age group would react, this means that at least 2,800 children are at risk to react to $17 \%$ of chocolate products because these products have no labelling regarding milk content. Similarly, at least 6,200 adults within the four countries are at risk to react to $17 \%$ of chocolate products. If it is included that about $25 \%$ of allergic consumers ignore the PAL, the number of products that constitute a risk would be even higher because 15 PAL products contained concentrations of casein that would cause reactions in more than $10 \%$ of the milk-allergic population. Almost 4 PAL products would thus constitute a risk and if these are added to the 7 products with no declaration of PAL, 11 out of 42 products would constitute a risk for $10 \%$ of the milk-allergic population. Thus, in total, at least 9,000 people within the Nordic population would be at risk to react to every fourth chocolate product that does not declare milk as an ingredient. In addition, these same 9,000 people would also be at risk to react to every twentieth bakery product that does not declare milk as an ingredient. 
When the calculations above have been made it is an interpretation that the results regarding milk in chocolate and bakery products reflect the overall chocolate and bakery products on the Nordic market. This might not be the case, however it is not possible to sample products from all producers and importers within the four countries. The sampled product categories were chosen on the basis of risk. A similar survey has been performed in the UK (6), which was followed by a risk assessment with a slightly different approach (7). Milk was found in ten PAL chocolate products and was calculated to cause a reaction in up to $50 \%$ of the milk-allergic population.

\section{Hazard characterization}

The severity of an allergic reaction can vary from mild eczema and stomach pain to vomiting, severe asthma, and anaphylactic shock, which could lead to death. There is a large variation in the dose that elicits a reaction between individuals, and there is also variation in the dose that can elicit a reaction in the same individual. For example, a dose corresponding to ED01 could give mild reactions in the most sensitive individuals, while a dose corresponding to ED10 could lead to severe reactions in a less sensitive cohort. This can be further emphasized by the allergy registry that the NFA maintains. Certain milk-allergic individuals claim to be able to eat chocolate products labelled with PAL for milk, but occasionally they have reacted. One milk-allergic boy reacted with eczema and a swollen throat to dark chocolate labelled with PAL for milk that contained $990 \mathrm{mg}$ casein $/ \mathrm{kg}$. His mother claimed that he had eaten chocolate bars of this brand previously. Three other chocolate bars of the same brand were analysed and contained 4.1 to $980 \mathrm{mg}$ casein $/ \mathrm{kg}$. A woman reacted with an anaphylactic reaction after eating approximately $20 \mathrm{~g}$ of dark chocolate labelled with PAL that contained $1,000 \mathrm{mg}$ casein $/ \mathrm{kg}$. This corresponds to a dose of $20 \mathrm{mg}$ casein and is well above ED10. The woman had previously eaten chocolate with PAL.

The incidence of food-induced anaphylaxis in the child/adolescent population was $29 / 100,000$ person years in Stockholm County in 2007 (8). In other words, in the Swedish youth population $0.03 \%$, or 608 children and adolescents, react with anaphylactic reactions annually. Milk causes $9 \%$ of these anaphylactic reactions, i.e. 55 reactions each year. One potential explanation for these reactions could be products that contain undeclared milk. However, food served in restaurants and 
schools and by family and friends should be included in this number (9). The NFA is, since 1993, aware of three deaths in Sweden caused by undeclared milk; two were children and one was an adult.

\section{Undeclared hazelnut}

Hazelnut was detected in 18 out of 299 products analysed for hazelnut (6\%, table 13). Hazelnut was detected in $15 \%$ of the products that were labelled with PAL with a range of 3.1-18,500 mg hazelnut/kg. Hazelnut was detected in $1.9 \%$ of products without PAL, and the range was 31-130 $\mathrm{mg}$ hazelnut $/ \mathrm{kg}$. All products in which hazelnut was detected were within the food categories chocolate/candy or bakery products (Table 14). 83 chocolate/candy products and 109 bakery products were analysed for hazelnut, thus 192 products in total.

\begin{tabular}{|c|c|c|c|c|}
\hline \multirow[t]{2}{*}{$\begin{array}{l}\text { Analysed } \\
\text { products }\end{array}$} & \multicolumn{2}{|c|}{$\begin{array}{l}\text { Undeclared hazelnut in products with PAL } \\
\text { (range } \mathrm{mg} / \mathrm{kg} \text { ) }\end{array}$} & \multicolumn{2}{|c|}{$\begin{array}{l}\text { Undeclared hazelnut in products without PAL } \\
\text { (range } \mathrm{mg} / \mathrm{kg} \text { ) }\end{array}$} \\
\hline & Number & $\%$ & Number & $\%$ \\
\hline 299 & $\begin{array}{l}14 \text { out of } 93^{\mathrm{a}} \\
\text { (range } 3.1-18,500 \mathrm{mg} / \mathrm{kg} \text { ) }\end{array}$ & $15 \%$ & $\begin{array}{l}4 \text { out } 206 \\
\text { (range } 31-130 \mathrm{mg} / \mathrm{kg} \text { ) }\end{array}$ & $1.9 \%$ \\
\hline
\end{tabular}

Note: $\quad a$ = Products labelled with PAL for hazelnut or for "nuts".

\section{Exposure assessment}

\section{Undeclared hazelnut - all products}

Fifteen of the 18 chocolate/candy and bakery products contained hazelnut at concentrations that would result in a dose above the ED01 when the relevant portion sizes are considered (Table 14). This means that $8 \%$ of these products that were analysed for hazelnut could be a risk for the most sensitive hazelnut-allergic consumers. Four chocolate/candy products $(2 \%$ of the chocolate/candy and bakery products analysed for hazelnut) contained hazelnut at concentrations that would result in a dose above the ED10 when the relevant portion size is considered. Compared to the scenario for milk, this is a smaller number of products. 


\begin{tabular}{|c|c|c|c|c|c|}
\hline Food category & $\begin{array}{r}\text { kg consumed/ } \\
\text { portion (95th } \\
\text { percentile) }\end{array}$ & $\begin{array}{r}\text { ED01 } \\
\text { (mg) }\end{array}$ & $\begin{array}{r}\text { Number of products } \\
\text { with a calculated } \\
\text { intake above ED01* }\end{array}$ & $\begin{array}{r}\text { ED10 } \\
\text { (mg) }\end{array}$ & $\begin{array}{r}\text { Number of products } \\
\text { with a calculated intake } \\
\text { above ED10* }\end{array}$ \\
\hline Chocolate/ candy & 0.138 & 0.64 & 13 & 43 & 4 \\
\hline Sweet bread & 0.136 & 0.64 & 2 & 43 & 0 \\
\hline Soft bread & 0.107 & 0.64 & 0 & 43 & 0 \\
\hline
\end{tabular}

Note: $\quad *$ The measurement uncertainty of the method was $30 \%$. When the measurement uncertainty is considered, one additional bakery product would be included in the ED01 column because the analysed concentration is close to the lower value that the $30 \%$ measurement uncertainty provides.

\section{Hazelnut in products with and without precautionary labelling for hazelnut/nuts}

These results are further divided in Figure 6 according to whether the products were labelled with PAL or not. Eleven of the hazelnutcontaining products labelled with PAL contained concentrations of hazelnut that would result in a dose well above ED01 when the relevant portion sizes are considered. Four of these products contained concentrations of hazelnut that also would result in a dose well above ED10 when the relevant portion sizes are considered. The ED50 is 80.6 $\mathrm{mg}$ hazelnut protein (4), which equals $516 \mathrm{mg}$ hazelnut. One of the chocolate products with PAL for hazelnut contained hazelnut at a concentration that would result in a dose above this value when the relevant portion size is considered.

All four of the hazelnut-containing products without PAL contained hazelnut that would result in a dose above the ED01 but below the ED10 when the relevant portion size is considered.

Approximately $2.2-4.5 \%$ of the adult population in Northern Europe is allergic to hazelnut (1). The figures are lower among children at approximately $0.1 \%$. According to Table 10 , this corresponds to approximately 701,000 people in the four Nordic countries. Four products labelled without PAL were above the ED01, when the relevant portion sizes are considered. This means that at least 7,000 adults and children are at risk to react to $2 \%$ of the chocolate/candy and bakery products. If it is included that about $25 \%$ of allergic consumers ignore the PAL, the number of products that constitute a risk would be higher. $25 \%$ of the 11 PAL products would then constitute a risk for more than $1 \%$ of the hazelnut-allergic population. Thus, more than 7,000 people in the Nordic population would be at risk to react to $4 \%$ of chocolate/bakery products that do not declare hazelnut as an ingredient. 


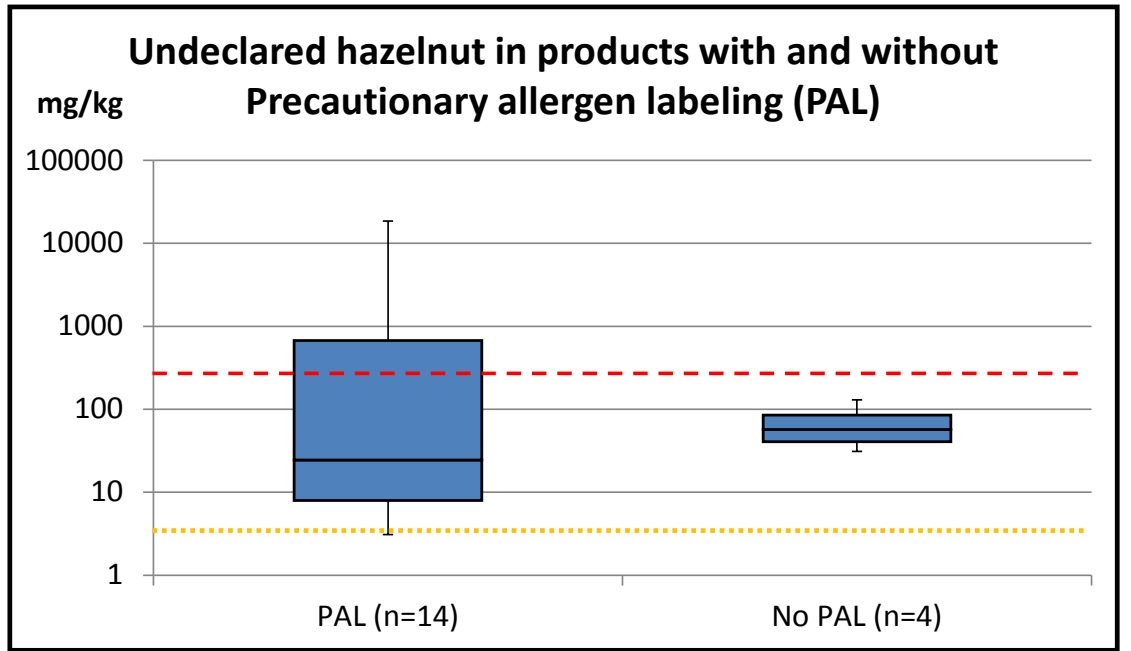

Note: The dotted yellow line and the red dashed line indicate the concentrations of hazelnut in chocolate and bakery products that would result in a dose equal to $\operatorname{ED01}(. .$.$) and \operatorname{ED} 10(---)$, respectively, when relevant portion sizes of chocolate and bakery products are considered.

\section{Hazard characterization}

Approximately $80 \%$ of hazelnut-allergic individuals in Northern Europe are sensitized to the birch pollen homologue hazelnut allergen Cor a 1 (2). These individuals often respond with mild symptoms such as itching of the throat. Other reactions vary from mild eczema and stomach pain to vomiting, severe asthma, and anaphylactic shock, which could lead to death. Sensitization towards Cor a 1 is especially common in the adult population. Hazelnut allergy is less frequent among children, but those children with an allergy might respond more severely. Three percent (18 cases) of anaphylactic reactions among the child/adolescent population in Stockholm County in 2007 were caused by hazelnut. One potential explanation for these reactions could be products that contain undeclared hazelnut. However, food served in restaurants and school restaurants and by family and friends should be included in this number (9). The NFA is aware of two deaths, since 1993, caused by undeclared hazelnut, both of which were children. 


\section{Undeclared peanut}

Peanut was detected in 8 out of 292 products analysed for peanut $(2.7 \%$, table 15). Peanut was detected in $17 \%$ of the products that were labelled with PAL, and these had a range of 0.7-42,500 mg peanut $/ \mathrm{kg}$. Peanut was detected in $1.1 \%$ of the products without PAL, and the range was 0.7-2.8 mg peanut/kg. The products, in which peanut was detected, were within the food categories chocolate/candy, bakery products and ready-made meals (instant noodles) (Table 16).

\begin{tabular}{|c|c|c|c|c|}
\hline \multirow[t]{2}{*}{$\begin{array}{l}\text { Analysed } \\
\text { products }\end{array}$} & \multicolumn{2}{|c|}{$\begin{array}{l}\text { Undeclared peanut in products with PAL } \\
\text { (range } \mathrm{mg} / \mathrm{kg} \text { ) }\end{array}$} & \multicolumn{2}{|c|}{$\begin{array}{l}\text { Undeclared peanut in products without PAL } \\
\text { (range } \mathrm{mg} / \mathrm{kg} \text { ) }\end{array}$} \\
\hline & Number & $\%$ & Number & $\%$ \\
\hline 292 & $\begin{array}{l}5 \text { out of } 29 \\
\text { (range } 0.7-42,500 \mathrm{mg} / \mathrm{kg} \text { ) }\end{array}$ & $17 \%$ & $\begin{array}{l}3 \text { out } 263 \\
\text { (range } 0.7-2.8 \mathrm{mg} / \mathrm{kg} \text { ) }\end{array}$ & $1.1 \%$ \\
\hline
\end{tabular}

Table 16: Number of products with undeclared peanut that contributes to doses that would constitute a risk for more than $1 \%$ (ED01) and 10\% (ED10) of the peanut-allergic consumers when the relevant portion sizes are considered

\begin{tabular}{|l|rrrrr|}
\hline Food category & $\begin{array}{r}\text { kg consumed/ } \\
\text { portion (95th } \\
\text { percentile) }\end{array}$ & $\begin{array}{r}\text { ED01 } \\
(\mathbf{m g})\end{array}$ & $\begin{array}{r}\text { Number of } \\
\text { products with a } \\
\text { calculated intake } \\
\text { above ED01* }\end{array}$ & $\begin{array}{r}\text { ED10 } \\
(\mathbf{m g})\end{array}$ & $\begin{array}{r}\text { Number of products } \\
\text { with a calculated intake } \\
\text { above ED10* }\end{array}$ \\
\hline Chocolate/candy & & & 3 & 13.6 & 1 \\
Sweet bread & 0.138 & 0.8 & 0 & 13.6 & 0 \\
Soft bread & 0.136 & 0.8 & 0 & 13.6 & 0 \\
Noodle wok & 0.107 & 0.8 & 0 & 13.6 & 0
\end{tabular}

Note: $\quad *$ The measurement uncertainty was $35 \%$. When the results were calculated with an added measurement uncertainty, no further products gave a dose above ED01 or ED10 when the relevant portion sizes were considered. The products reported in the Table still exceeded the ED01 or ED10 when calculated with the measurement uncertainty.

Five of the eight products that contained peanut contained concentrations of peanut that would result in a dose below ED01, when the relevant portion sizes are considered. Three of the chocolate/candy products, that were labelled with PAL for peanut, contained peanut at concentrations that would result in a dose above ED01 when the relevant portion sizes were considered. The ED50 for peanut is $67.3 \mathrm{mg}$ peanut protein which equals $269 \mathrm{mg}$ peanut (4). One of the products contained very high concentrations of peanut which would result in a dose well above ED50 and thus at least $50 \%$ of the peanut-allergic individuals would react to this product. Because only three products were calculated to cause a reaction 
in more than $1 \%$ of the peanut-allergic population, no exposure assessment or hazard characterization were made.

\section{Undeclared egg}

Egg-white protein was detected in 6 out of 259 products analysed for egg-white protein $(2.3 \%$, Table 17). Egg-white protein $(27 \mathrm{mg}$ egg-white protein $/ \mathrm{kg}$ ) was detected in one of the products that was labelled with PAL (7.1\%) and in $1.9 \%$ of products without PAL (range $0.4-550 \mathrm{mg}$ egg-white protein $/ \mathrm{kg}$ ). The products in which egg-white protein was detected were within the food categories bakery products and readymade meals (soup and salad) (Table 18).

Table 17: Egg-white protein detected and quantified in products with and without Precautionary Allergen Labelling (PAL)

\begin{tabular}{|c|c|c|c|c|}
\hline \multirow[t]{2}{*}{$\begin{array}{l}\text { Analysed } \\
\text { products }\end{array}$} & \multicolumn{2}{|c|}{$\begin{array}{l}\text { Undeclared egg-white protein in products } \\
\text { with PAL (range } \mathrm{mg} / \mathrm{kg} \text { ) }\end{array}$} & \multicolumn{2}{|c|}{$\begin{array}{l}\text { Undeclared egg-white protein in products } \\
\text { without PAL (range } \mathrm{mg} / \mathrm{kg} \text { ) }\end{array}$} \\
\hline & Number & $\%$ & Number & $\%$ \\
\hline 259 & $\begin{array}{l}1 \text { out of } 14 \\
(27 \mathrm{mg} / \mathrm{kg})\end{array}$ & $7.1 \%$ & $\begin{array}{l}5 \text { out of } 245 \\
\text { (range } 0.4-550 \mathrm{mg} / \mathrm{kg} \text { ) }\end{array}$ & $1.9 \%$ \\
\hline
\end{tabular}

Table 18: Number of products with undeclared egg-white protein that result in doses that would constitute a risk for more than $1 \%$ (ED01) and $10 \%$ (ED10) of the egg-allergic consumers, respectively, when the relevant portion sizes are considered

\begin{tabular}{|c|c|c|c|c|c|}
\hline Food category & $\begin{array}{r}\text { kg consumed/ } \\
\text { portion } \\
\text { (95th percentile) }\end{array}$ & $\begin{array}{r}\text { ED01 } \\
\text { (mg) }\end{array}$ & $\begin{array}{r}\text { Number of products } \\
\text { with a calculated } \\
\text { intake above ED01* }\end{array}$ & $\begin{array}{l}\text { ED10 } \\
\text { (mg) }\end{array}$ & $\begin{array}{l}\text { Number of products } \\
\text { with a calculated } \\
\text { intake above ED10* }\end{array}$ \\
\hline Sweet bread & 0.136 & 0.025 & 2 & 1.1 & 2 \\
\hline Soft bread & 0.107 & 0.025 & 2 & 1.1 & 0 \\
\hline Pasta salad & 0.300 & 0.025 & 1 & 1.1 & 0 \\
\hline Soup & 0.500 & 0.025 & 1 & 1.1 & 0 \\
\hline
\end{tabular}

All six products that contained egg-white protein would result in doses above ED01, i.e. a dose that more than $1 \%$ of the most sensitive eggallergic individuals would react to when the relevant portion sizes are considered. The LOQ of the method is $0.5 \mathrm{mg}$ egg-white protein $/ \mathrm{kg}$, and three products were below or at this value but above the LOD of $0.3 \mathrm{mg}$ egg-white protein $/ \mathrm{kg}$. Two of the bakery products contained egg-white protein at concentrations that would contribute to a dose that at least $10 \%$ of the egg-allergic consumers would react to. No exposure 
assessment or hazard characterization were made because undeclared egg occurred in different food categories.

\section{Undeclared gluten}

Gluten was detected in 7 out of 167 products analysed for gluten (4.2\%, table 19). Gluten (6.4 mg gluten $/ \mathrm{kg}$ ) was detected in one of the products that was labelled with PAL (3.3\%) and in $4.4 \%$ of products without PAL (range 6.6-27 mg gluten $/ \mathrm{kg}$ ). The products in which gluten was detected were within the food categories bakery products, chocolate/candy, soya steak, and pâté (Table 20).

Although products labelled "gluten-free" were not intended to be included in the project, two products with such labelling were sent to the laboratory and therefore analysed. The "Commission Regulation (EC) No $41 / 2009$ of 20th January 2009 concerning the composition and labelling of foodstuffs suitable for people intolerant to gluten" regulates products labelled with the wording "gluten-free". The concentration of gluten should not exceed $20 \mathrm{mg}$ gluten $/ \mathrm{kg}$, but one product contained $21 \mathrm{mg}$ gluten $/ \mathrm{kg}$ and another contained $27 \mathrm{mg}$ gluten $/ \mathrm{kg}$. The measurement uncertainty for the gluten analysis is $35 \%$, and thus it cannot be ruled out that the products actually contain gluten below the threshold of $20 \mathrm{mg}$ gluten $/ \mathrm{kg}$.

Celiac disease (gluten intolerance) is triggered by gluten proteins present in wheat, rye, and barley. The gluten proteins cause an inflammation of the mucosa in the small intestine leading to flattening of the mucosa and, when the illness is untreated, to malnutrition. Celiac disease is a life-long, permanent intolerance to gluten, and cereals like wheat, rye, and barley must be excluded from the diet. The thresholds for labelling products with "gluten-free" and "very low gluten" $(20 \mathrm{mg}$ gluten $/ \mathrm{kg}$ and $100 \mathrm{mg}$ gluten $/ \mathrm{kg}$, respectively) have been set to be safe for people with celiac disease (10). The analysed products should thus not constitute a risk for people with celiac disease.

\begin{tabular}{|c|c|c|c|c|}
\hline \multirow[t]{2}{*}{$\begin{array}{l}\text { Analysed } \\
\text { products }\end{array}$} & \multicolumn{2}{|c|}{$\begin{array}{l}\text { Undeclared gluten in products } \\
\text { with PAL (range } \mathrm{mg} / \mathrm{kg} \text { allergen) }\end{array}$} & \multicolumn{2}{|c|}{$\begin{array}{l}\text { Undeclared gluten in products } \\
\text { without PAL (range } \mathrm{mg} / \mathrm{kg} \text { allergen) }\end{array}$} \\
\hline & Number & $\%$ & Number & $\%$ \\
\hline 167 & $\begin{array}{l}1 \text { out of } 30^{a} \\
(6.4 \mathrm{mg} / \mathrm{kg})\end{array}$ & $3.3 \%$ & $\begin{array}{l}6 \text { out of } 137 \\
\text { (range } 6.6-27 \mathrm{mg} / \mathrm{kg} \text { ) }\end{array}$ & $4.4 \%$ \\
\hline
\end{tabular}

Note: $\quad \mathrm{a}=$ Products labelled with PAL for gluten, wheat, or other gluten-containing grains. 
Wheat protein and wheat allergy were not included in the risk assessment guide. This was partly due to the fact that the ED01 and ED10 for milk, egg, hazelnut, and peanut are based on more food challenges and therefore the numbers are considered to have a higher statistical power. However, food challenges have been performed on patients with wheat allergy, and the ED05 is presented table 20.

Table 20: Number of products with undeclared gluten that would result in a dose (ED05) that would constitute a risk for more than $5 \%$ of the wheat-allergic consumers when the relevant portion sizes are considered

\begin{tabular}{|c|c|c|c|}
\hline Food category & $\begin{array}{l}\mathrm{kg} \text { consumed/portion } \\
\text { (95th percentile) }\end{array}$ & $\mathrm{EDO5}^{\mathrm{a}}$ (mg) & $\begin{array}{l}\text { Number of products with a calculated } \\
\text { intake above ED } 05^{\mathrm{a}}\end{array}$ \\
\hline Sweet bread & 0.136 & 1.25 & $\begin{array}{l}0 . \text { But this would be } 1 \text { if the } \\
\text { measurement uncertainty of the } \\
\text { method is included. }\end{array}$ \\
\hline Soft bread & 0.107 & 1.25 & 0 \\
\hline Chocolate/ candy & 0.138 & 1.25 & 2 \\
\hline Pâtéb & 0.198 & 1.25 & 1 \\
\hline Soya steak ${ }^{b}$ & 0.198 & 1.25 & 1 \\
\hline
\end{tabular}

Note: $\quad a=$ The value of $1 \mathrm{mg}$ wheat protein was recalculated to gluten, which makes up approximately $80 \%$ of the wheat proteins (12).

$b=$ The average 95th percentile of consumption of sausages was used for portion sizes of pâté and soya steak.

Five of the seven products with detectable gluten contained concentrations that result in a dose that could cause a reaction in more than $5 \%$ of the most sensitive wheat-allergic consumers when the relevant portion sizes are considered. The analysed concentrations were close to the calculated ED05 dose when the relevant portion sizes were considered. Thus, no exposure assessment or hazard characterization were performed.

\section{Conclusions}

Milk protein, hazelnut, peanut, egg-white protein and gluten were all detected in products analysed within the project. For all five allergens, concentrations were found that would result in a dose that causes reactions in more than $1 \%$ of the individuals who are allergic to milk, hazelnut, peanut, egg or wheat allergens, when the relevant portion sizes are considered. The occurrence of these allergens varied, with milk being the most commonly undeclared allergen. Based on these results we conclude that in total, at least 9,000 people within the four Nordic countries would be at risk to react to every fourth chocolate product studied and to every twentieth bakery product studied that does not 
declare milk as an ingredient. We further conclude that more than 7,000 people within the four Nordic countries would be at risk to react to $4 \%$ of chocolate/candy and bakery products studied, that do not declare hazelnut as an ingredient. No exposure assessment was made for the other allergens (peanut, egg, and wheat) because these allergens occurred undeclared less frequently and/or in lower concentrations.

High concentrations of casein (milk protein), hazelnut and peanut were found in certain chocolate products with precautionary allergen labelling. These doses would result in doses above the ED50 when the relevant portion size was considered, meaning that more than $50 \%$ of those with milk, hazelnut or peanut allergy might react to these products.

Undeclared allergens can cause reactions like eczema, stomach pain, vomiting, asthma, and anaphylactic shock, which could lead to death, but the severity of the allergic reaction is difficult to predict. Milk is the most commonly undeclared allergen to cause allergic reactions in Sweden (13). Milk has been confirmed to cause three deaths and hazelnut has been confirmed to cause two deaths in Sweden since 1993. Among children in Sweden, milk and hazelnut account for approximately 55 and 18 anaphylactic reactions, respectively, each year (6).

\section{Acknowledgements}

We are grateful to Charlotte B. Madsen at the Technical University of Denmark for reviewing the text. We are also grateful to the participating food inspectors for performing the food control. We would also like to thank the Biology department at the Swedish Food Agency for performing the analyses.

\section{References}

1. Scientific Opinion on the evaluation of allergenic foods and food ingredients for labelling purposes. EFSA Panel on Dietetic Products, Nutrition and Allergies (NDA). EFSA Journal 2014;12(11):3894.

2. Sjögren Bolin Y. Undeclared milk, peanut, hazelnut or egg - guide on how to assess the risk of allergic reactions in the population. Livsmedelsverkets rapport 17/2015. www.livsmedelsverket.se

3. Study on the impact of food information on consumers' decision making. TNS European Studies Consortium. December 2014. http://ec.europa.eu/food/safety/ docs/labelling_legislation_study_food-info-vs-cons-decision_2014.pdf 
4. Blom WM et al. Threshold dose distributions for 5 major allergenic foods in children. J Allergy Clin Immunol. 2013;131:172-9.

http://dx.doi.org/10.1016/j.jaci.2012.10.034

5. Population statistics 2016. www.scb.se, www.ssb.no, www.dst.dk/befolkning, www.stat.fi

6. Barabara Hirst. Survey of allergen advisory labelling and allergen content of UK retail pre-packed processed foods. Food Standards Agency 2014. www.fsa.uk

7. Remington BC et al. Unintended allergens in precautionary labelled and unlabeled products pose significant risks to UK allergic consumers. Allergy 2015;70:813-19. http://dx.doi.org/10.1111/all.12625

8. Vetander M, Helander D et al. Anaphylaxis and reactions to foods in children - a population-based case study of emergency department visits. Clin Exp Allergy 2012;42:568-77. http://dx.doi.org/10.1111/j.1365-2222.2011.03954.x

9. Verselius A et al. Frequency, severity and causes of unexpected allergic reactions to food: a systematic literature review. Clin Exp Allergy 2015;45:347-67. http://dx.doi.org/10.1111/cea.12328

10. Hischenhuber C et al. Aliment Pharmacol Ther 2005;23:559-75.

11. Taylor SL et al. Establishment of reference doses for residues of allergenic foods: Report of the VITAL Expert Panel. Food and Chemical Toxicology 2014;63:9-17. http://dx.doi.org/10.1016/j.fct.2013.10.032

12. Lindahl L. Glutens kemiska och fysikaliska egenskaper. Livsmedelsteknik 1985;4:144-46.

13. Ferm M and Sjögren Y. Milk, the most commonly undeclared food allergen causing unexpected allergic reactions in Sweden 2004-2011. www.slv.se 


\section{Appendix 3: \\ Products with undeclared allergens, divided by country}

Table 21: Number of products with undeclared allergens, including no precautionary allergen labelling for the allergen, according to the analytical results. Results divided by country

\begin{tabular}{lrrrrr} 
& Milk protein & Egg white protein & Gluten & Hazelnut & Peanut \\
Denmark (78 products) & $3(3.8 \%)$ & $1(1.3 \%)$ & $1(1.3 \%)$ & $3(3.8 \%)$ & $1(1.3 \%)$ \\
Finland (33 products) & $1(3.0 \%)$ & & $1(3.0 \%)$ & & \\
Norway (97 products) & $2(2.1 \%)$ & $1(1.0 \%)$ & & & \\
Sweden (131 products) & $10(7.6 \%)$ & $3(2.3 \%)$ & $4(3.1 \%)$ & $1(0.76 \%)$ & $2(1.5 \%)$ \\
\hline
\end{tabular}

Note: In the first column the numbers in the brackets describe the number of products controlled in each country. The percentages in the brackets in the following columns therefore describe how many percent of the products controlled in each country these constitute. 
Nordic Council of Ministers

Ved Stranden 18

DK-1061 Copenhagen K

www.norden.org

\section{Undeclared allergens in food}

Denmark, Finland, Norway and Sweden collaborated during 2015 in a control project on allergen labeling. Products were also analysed for the allergens milk, egg, hazelnut, peanut and gluten.

Correct labeling is the only aid for allergic consumers to avoid products which could pose a serious health risk. The widespread use of non-regulated precautionary allergen labeling (PAL) might decrease the amount of products available for allergic consumers. It can also pose a risk since the PAL might be ignored.

On $10 \%$ of the controlled products, the allergenic ingredients were not correctly transcribed in the list of ingredients and EU regulations were thus not followed. Milk was the most frequently found undeclared allergen, especially in chocolate and bakery products, and therefore constitute a risk for allergic consumers. The results might give input to achieve EU legislation regarding PAL.

TemaNord 2016:528

ISBN 978-92-893-4606-1 (PRINT)

ISBN 978-92-893-4607-8 (PDF)

ISBN 978-92-893-4608-5 (EPUB)

ISSN 0908-6692

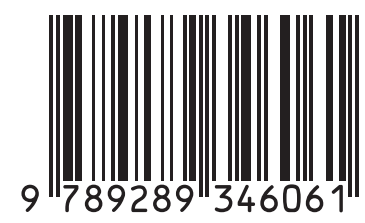

